\title{
A competitive advantage from the implementation timing of ISO management standards
}

\author{
Hung-Chung $\mathrm{Su}^{\mathrm{a}, *}$, Suvrat Dhanorkar ${ }^{\mathrm{b}}$, Kevin Linderman $^{\mathrm{c}}$ \\ a Operations Management, College of Business, University of Michigan-Dearborn, Dearborn, MI, United States \\ b Supply Chain Management, Smeal College of Business, Pennsylvania State University, University Park, PA, United States \\ ' Supply Chain and Operations, Carlson School of Management, University of Minnesota, Minneapolis, MN, United States
}

\section{A R T I C L E I N F O}

\section{Article history:}

Received 8 February 2014

Received in revised form 17 February 2015

Accepted 17 March 2015

Available online 17 April 2015

Accepted by D.R. Guide

\section{Keywords:}

ISO 9001

ISO 14001

Management standards

Competitive strategy

Absorptive capacity

Early mover advantage

\begin{abstract}
A B S T R A C T
With the rise of globalization, firms increasingly implement management standards developed by the International Organization for Standardization (ISO) to assure they can meet their customers' expectations. ISO management standards reduce performance variability among suppliers and promote global trade. However, ISO standards also promote a certain degree of commonality or isomorphism between firms. If the very notion of 'standards' encourages a certain level of commonality between firms, then how can firms achieve a competitive advantage from implementing ISO standards? This research argues that the timing of when a firm implements an ISO standard relative to their rivals has strategic benefits. Drawing on the competitive dynamics literature we argue that firms can achieve an early mover advantage when implementing ISO 14001. However, an early mover advantage depends on the level of a firm's absorptive capacity (prior experience with ISO 9001) and the competitive intensity of their industry. This study uses longitudinal data from firms that implemented ISO 14001 at varying points in time to examine the benefits of an early mover advantage. More broadly, this research sheds light on when firms benefit the most from implementing new management standards. The results provide insights into implementing other emerging management standards.
\end{abstract}

(c) 2015 Elsevier B.V. All rights reserved.

\section{Introduction}

Increasingly firms implement ISO (International Organization for Standardization) management standards as a strategic initiative to remain competitive (King et al., 2005). For example, Ford set a strategic goal to have all its manufacturing plants ISO 14001 certified worldwide by 1998 (Wilson, 2001). IBM had set a similar strategic goal of worldwide ISO 14001 certification (Morrow and Rondinelli, 2002). Many organizations have dedicated corporate level resources to evaluate, monitor and implement new management standards across the organization. For example, 3M has their Strategic Quality Leadership Team take responsibility for administering various management standards like ISO 9001 and ISO 14001. This team "sets strategy, identifies common opportunities for improvement, and directs global synergy across all business units within 3M" (3M, 2012). As a result, firms not only make

\footnotetext{
* Corresponding author.

E-mail addresses: hcsu@umich.edu (H.-C. Su),dhanorkarsuvrat@gmail.com (S. Dhanorkar), linde037@umn.edu (K. Linderman).
}

strategic decisions to implement management standards, but also look for synergies across standards.

Given the strategic nature of ISO standards implementation, the question becomes how does implementing a standard generate a competitive advantage? Strategy scholars argue that a competitive advantage comes from firm heterogeneity. For instance, the resource-based view (RBV) of the firm argues that developing unique, valuable, rare and non-replicable resources help firms gain a competitive advantage over rivals and generates rent profits (Barney, 1991). However, ISO standards promote a certain degree of commonality or isomorphism between firms. For example, customers may require their suppliers to get ISO 9001 certified to assure a certain level of quality performance. ISO 9001 certification reduces the heterogeneity between suppliers in terms of quality performance. If the very notion of 'standards' encourages a certain level of homogeneity between firms, how can firms achieve a competitive advantage from implementing ISO standards?

Research is inconclusive on the competitive benefits of implementing ISO standards. For example, some research has found a positive impact of ISO 9001 on performance (Corbett et al., 2005; Levine and Toffel, 2010; Naveh and Marcus, 2005), while other studies do not show a significant relationship (Martínez-Costa et al., 
2009; Singh et al., 2011; Terziovski et al., 1997). Furthermore, Benner and Veloso (2008) showed that ISO 9001 implementation has performance benefits but these benefits diminish over time, which calls into question the long term benefits of implementing standards. Research on ISO 14001 has yielded similar results, some studies found that implementing ISO 14001 had performance benefits (de Jong et al., 2014) while others did not find support (Heras-Saizarbitoria et al., 2011; Link and Naveh, 2006). Collectively these mixed results call into question how can firms gain a competitive advantage through ISO standards? One may question if there is ultimately any competitive advantage at all from implementing ISO standards. In addition, despite the mixed evidence on the competitive benefits of ISO standards, firms continue to implement these standards. For example, research shows that ISO standards diffuse over time (Corbett, 2006; Corbett and Kirsch, 2001), and firms may implement ISO standards regardless of their performance benefits (Nair and Prajogo, 2009; Yeung et al., 2011). Consequently, the question managers' increasingly face is not if they should implement the new standard, but when they should implement it.

This research argues that the timing decision of when firms implement ISO standard has strategic benefits, specifically an early-mover advantage can lead to performance benefits. The competitive dynamics literature (Barnett and McKendrick, 2004; D'Aveni et al., 2010; Lieberman and Montgomery, 1988; Young et al., 1996) provides a theoretical explanation of the strategic benefits for the implementation timing of new standards. This perspective argues that implementing new practices is similar to participating in a race with rival peers (Barnett and McKendrick, 2004). Only firms that outpace their rivals gain a competitive advantage. In other words, the potential performance benefits come from implementing practices earlier than rivals. Consequently, firms can gain a temporary competitive advantage from the timing of their implementation even though ISO standards tend to reduce firm heterogeneity (D'Aveni et al., 2010). We further argue that the performance benefits of the timing decision depends on level of industry competitiveness as well as the firm's absorptive capacity. Given the perspective that firms participate in an ongoing race with rivals, the level of competition should influence the effectiveness of implementation timing (D'Aveni, 1994). In addition, various ISO standards share many common features, which makes them structurally compatible with one another. This allows organizations to apply knowledge accumulated from one standard to another standard. Consequently, a firm's absorptive capacity (i.e. the accumulated stock of related knowledge from previous standards) (Zahra and George, 2002) should influence the performance benefits from the timing of ISO standard implementation. Further, with the growth of increasingly more management standards ${ }^{1}$, the decision of when to implement the next standard will become increasingly important. Taking all these factors together, deciding when to implement the next ISO management standard is highly complex, yet strategically important.

This research empirically investigates the effect of the timing decision of when to implement an ISO standard on performance through an analysis of longitudinal data. The analysis uses ISO 9001/ISO 14001 certification data and business performance data. The organizations in the study come from five different industries with varying levels of competitive intensity. All firms in our study implemented ISO 14001 at varying points in time, which allows us to

\footnotetext{
1 Since the introduction of the ISO 9001 (quality management) standard in 1987, the Organization for International Standards (ISO) has developed several other standards such as ISO 14001 (environmental management), ISO 26001 (social responsibility), ISO 28001 (supply chain security and resilience), and ISO 13053 (Six Sigma).
}

isolate the effect of the timing decision on performance from the implementation decision itself. The results show that the timing of when firms implement ISO 14001 relative to their rivals has performance implications. However, this performance relationship is moderated by the level of competitive intensity and the amount of absorptive capacity the firm has from a related standard (ISO 9001).

This study offers theoretical and practical insights on deciding when to implement new management standards, which potentially has broader implications for implementing other emerging standards like ISO 28001. Researchers will likely investigate the performance benefits of implementing these emerging standards, however, we believe that the competitive advantage, although temporary, comes from the timing of implementation since these practices tend to reduce firm heterogeneity. As a practical matter, managers need to assess the relative benefits of quickly implementing new management standards. In addition, they need to recognize the temporary nature of the performance benefits, and these benefits depends on the level of competitive intensity of their industry and their prior experience with implementing other related standards.

The rest of the paper has the following organization: Section 2 reviews the literature, Section 3 theoretically develops the hypotheses, Section 4 describes the research methodology, and Sections 5-7 present the empirical results. Finally, Section 8 discusses the findings and present broader implications.

\section{Literature review}

\subsection{ISO management standards-ISO 9001 and ISO 14001}

The ISO management standards consist of a set of requirements that organizations must meet in order to receive a certificate of compliance. Independent auditors from third parties determine if the standards have been met, and issue a certificate of compliance if a facility met the requirements. A given organization may have multiple facilities with ISO certifications. Facilities need to re-certify every three years to maintain their ISO certification. ISO management standards share common features, making them structurally compatible. "Compatibility means that common elements of the [ISO] standards can be implemented in a shared manner" (Smith, 2006), which allows knowledge accumulated from one standard to be applied to another standard. The International Organization for Standardization (ISO) has a goal of enhancing compatibility among the different standards. ISO 9001 and 14001 follow identical compliance procedures and are rooted in the same ideology (Boiral, 2011). They share the same requirements for document control, management policy, operations control, training, auditing, monitoring and evaluation (Corbett and Kirsch, 2001).

The ISO 9001 standard gives the requirements for a quality management system. This standard helps ensure that customers get consistent, good quality products and services ${ }^{2}$. Customers will be assured a base level of quality performance when they purchase from an ISO certified business. According to Corbett and Kirsch (2001), ISO 9001 certified facilities had been growing at a rate of 50,000 to 60,000 every year worldwide. As of 2011 , more than 1.1 million ISO 9001 certifications have been issued worldwide (ISO, 2012), and it is one of the most widespread management standards developed by ISO (Corbett, 2006). This broad level of adoption has globally promoted more consistent quality performance across many different industries.

The ISO 14001 standard specifies the requirements for an environmental management system, which includes identifying

\footnotetext{
2 http://www.iso.org/iso/iso_9000.
} 


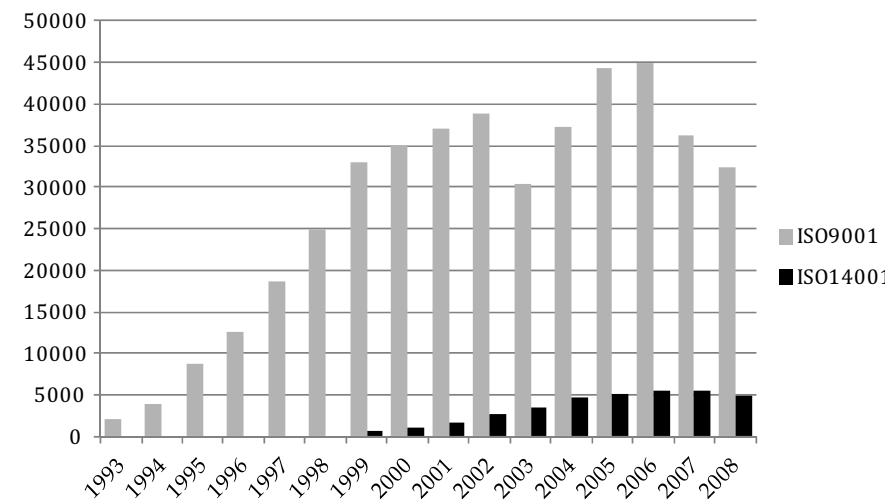

Fig. 1. ISO certification intensity in USA (Source: ISO Survey, 2008).

environmental liabilities, recording pollution and waste levels, ensuring safe disposal of hazardous materials. The implementation of ISO 14001 standards has been rapidly growing (see Fig. 1). Albuquerque et al. (2007) showed that the implementation rate of ISO 14001 has been much faster than ISO 9001.

Research shows that organizations benefit from implementing ISO standards. The ISO 9001 reduces quality defects, lowers cost and improves asset utilization (Benner and Veloso, 2008; Corbett et al., 2005; Gray et al., 2015; Terziovski et al., 2003). Similarly, studies show that implementing ISO 14001 reduces waste, pollution, and enhances environmental performance (Link and Naveh, 2006). But, several studies report mixed results with respect to financial performance (Link and Naveh, 2006; Montabon et al., 2000). However, these studies simply looked at the effect of implementation of the ISO standard on performance, and did not consider how implementation timing might impact financial performance.

\subsection{Competitive dynamics and early-mover advantage}

Recent research has begun to suggest that a competitive advantage is rare and may only persist for a short period of time (Wiggins and Ruefli, 2002). Several researchers have argued that it is difficult to gain a sustainable competitive advantage using firm-specific resources (D'Aveni, 1994; D’Aveni et al., 2010). Instead of looking at how static resources can help achieve a competitive advantage, researchers have started taking an action-based perspective to understand competitive advantage. From this perspective, a competitive advantage is more temporary in nature and comes from a firm's competitive actions and reactions (Grimm et al., 2005). This competitive dynamics perspective argues that a competitive advantage comes from a specific action or a stream of actions that a focal firm and its rivals take. Research in competitive dynamics emphasizes the characteristics of the firm's actions (e.g. timing, frequency or type) and their rivals' responses (Barnett and McKendrick, 2004; Miller and Chen, 1994; Young et al., 1996). One characteristic of an action considered in this literature stream is an early-mover advantage. The concept of early-mover advantage refers to the performance benefits gained from taking a competitive action early such as early market entry, new product introduction, or the implementation of a new process (Lieberman and Montgomery, 1988). The competitive dynamics perspective views gaining competitive advantage as an ongoing race with rival peers (Barnett and McKendrick, 2004). Only firms that outpace their competitors gain a "temporary monopoly" advantage (Schumpeter, 2008) and reap additional performance benefits.

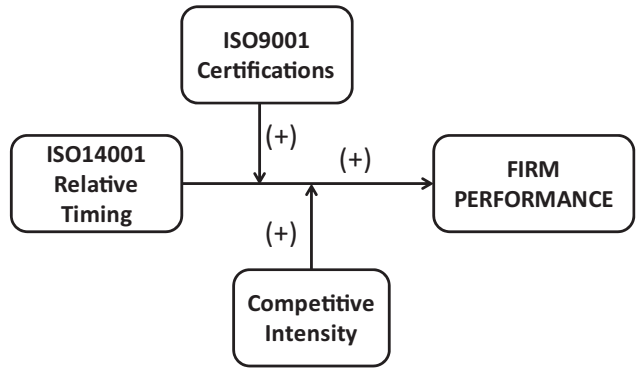

Fig. 2. Basic conceptual model.

\subsection{Absorptive capacity}

Cohen and Levinthal (1989) first describe absorptive capacity as the "ability to identify, assimilate, and exploit knowledge from the environment" (1989: p. 569). They argued that absorptive capacity reflects a firm's learning potential determined by their prior related knowledge, which they called the "cumulativeness feature" (Cohen and Levinthal, 1990). Zahra and George (2002), in their seminal article, re-conceptualized and clarified the concept of absorptive capacity. They argued that absorptive capacity has four dimensions: acquisition, assimilation, transformation and exploitation. The exploitation dimension relates to organizational learning, where organizational learning has been defined as "the organization's ongoing effort to better use knowledge to improve its actions (Lapré and Nembhard, 2011: p. 6)." Zahra and George (2002) describe the exploitation dimension as "routines that allow firms to refine, and extend existing competencies or create new ones by incorporating acquired and transformed knowledge into its operations (p. 190)." Zahra and George (2002) stated that Cohen and Levinthal's notion of absorptive capacity represents the 'exploitation' dimension of absorptive capacity, which could be built from past experience and allows firms to better exploit newly acquired knowledge (Zahra and George, 2002). In other words, the exploitation-based absorptive capacity helps firms exploit newly acquired knowledge, by leveraging existing related competencies (Zahra and George, 2002). As a result, the exploitation dimension relates to how a firm's accumulated knowledge from ISO 9001 implementation could influence ISO 14001 implementation.

\section{Theory and hypotheses development}

Fig. 2 depicts the conceptual model under investigation. This section first draws on the competitive strategy literature (Barnett and McKendrick, 2004; Lieberman and Montgomery, 1988; Young et al., 1996) to develop the baseline theory that explains how the timing of ISO 14001 implementation affects firm performance and then argues that the competitive intensity of the firm's industry and the firm's exploitation-based absorptive capacity (Cohen and Levinthal, 1990; Zahra and George, 2002) moderate the effect of implementation timing on firm performance.

\subsection{ISO 14001 implementation timing and early-mover advantage}

Empirical research generally supports the notion of early-mover advantage. For example, Ferrier et al. (1999) showed that when firms create new innovations and adopt new technologies faster than their rivals, they increase their performance and competitive positions in terms of industry market share. Similarly, Miller and Chen (1994) showed that when firms move slower than their peers, they have more negative performance outcomes. A meta-analysis by VanderWerf and Mahon (1997) found a significant relationship 
between an early-mover advantage and market share. Carow et al. (2004) extends the early-mover advantage to adopting organizational practices, and found that firms gain a competitive advantage from early adoption and have higher financial returns.

The competitive dynamics literature helps explain why firms should get an early-mover advantage when implementing ISO 14001. ISO standards are arguably static resources that can ultimately be imitated by other firms and consequently promote homogeneity across firms. As more firms implement ISO 14001 standards, the heterogeneity between firms decreases. However, when firms implement ISO 14001 earlier than their rivals, they obtain a temporary competitive advantage which has positive performance benefits. That is, they temporarily gain a certain level of heterogeneity over their rivals that implement later. The competitive dynamics literature would suggest that the timing of the implementation decision is a competitive action, even though the resource can ultimately be imitated. In addition, firms implementing later would not get a performance advantage since late implementation only further increases homogeneity with rival firms. In general, an early mover gets a benefit since an "early entrant can have a major influence on how attributes are valued and on the ideal attribute combination" (Carpenter and Nakamoto, 1989: p. 286). As a result, early movers of ISO 14001 should get benefits by showing their commitment to the environment before their competitors. This benefit helps them gain greater market access (profit opportunities) to customers that are sensitive to environmental issues (Bansal and Hunter, 2003). Taken together, the above discussion suggests the following hypothesis:

Hypothesis 1. (H1): Early ISO 14001 implementation timing relative to industry rivals positively affects firm performance.

\subsection{The moderating role of competitive intensity}

Strategy researches have long emphasized the contingent nature of early-mover advantage (Lieberman and Montgomery, 1988). The premise of an early-mover advantage depends on exploiting the potential opportunities earlier (by acting earlier) than rivals to maximize the firm's performance benefits. Nonetheless, the potential 'size' of the benefit that a firm can extract from its operating environment is influenced by the extent of competition (Dess and Beard, 1984). Competitive intensity refers to the degree to which a firm faces competition within its operating environment (D'Aveni, 1994). Following previous research, we define the level of competitive intensity as the inverse of industry concentration (Dess and Beard, 1984). High competitive intensity indicates a less concentrated market with more competitors and fewer dominant firms, while low competitive intensity indicates a more concentrated market with fewer competitors and more dominant firms.

In a less competitive environment, economic theory suggests that a smaller number of dominant firms will monitor each other's actions more carefully and tacitly coordinate their actions in an effort to further limit competition (Scherer and Ross, 1990). In this setting, firms are more aware of their mutual dependence due to high market concentration. Hence, the tendency to implement a newer management standard will likely increase costs and reduce profits for all firms. Firms' actions in a less competitive environment (high industry concentration) are much more likely to receive greater attention from competitors due to the high level of mutual awareness (Bain, 1951). Therefore, in less competitive environment, rival firms are more sensitive to the actions of a focal firm. They are also more ready and willing to respond to those actions, and quickly counteract any negative effects of not responding. Perhaps more importantly, rival firms are more inclined to respond quickly in a less competitive environment to signal to the focal firm that breaking their tacit collusion will be severely punished
(Scherer and Ross, 1990). Thus, in a less competitive environment, we posit that a firm's early-mover actions will be less effective due to quick responses from rivals, which quickly erodes any potential benefits they may gain from acting early.

On the other hand, in a highly competitive environment (less industry concentration), there are more competitors with less concentration in the same industry. Due to the large number of competitors, it is more difficult for firms to monitor and keep track of every competitor's movements. A specific firm's actions are less likely to be noticed and tend not to provoke immediate responses from rivals' since it is more difficult to monitor all their competitors. Furthermore, rivals tend to respond slower because it takes a longer time for them to realize the performance consequences of the firm's actions. As a result, early implementation of ISO 14001 may actually be more effective in a highly competitive environment. As Scherer and Ross stated in their study of industrial market structure, "as the number of sellers increase ... individual producers are increasingly apt to ignore the effect of price and output decisions on rival reactions" (1990: p. 277). Thus, firms' proactive actions are more likely to extract performance benefits in a highly competitive environment. As a result, firms implementing ISO 14001 standards earlier in highly competitive environments gain more benefits, which suggests the following hypothesis:

Hypothesis 2. (H2): Early ISO 14001 implementation timing relative to industry rivals increases firm performance to a greater degree in a high competitive intensity environment than in a low competitive intensity environment.

\subsection{The moderating role of absorptive capacity}

Drawing on the exploitation-based view of absorptive capacity, we argue that prior experience with ISO 9001 enhances the early implementer's ability to exploit the benefits of ISO 14001. Early ISO 14001 adopters often have limited knowledge about how to implement the standard. However, over time industry level knowledge about how to implement the standard tends to accumulate. Industry consultants, professional societies, and government agencies document implementation experiences that can help guide a firm's implementation of ISO 14001. For example, the Environmental Protection Agency (EPA) has developed guidelines for implementing an environmental management system based on ISO 14001 for the chemical industry ${ }^{3}$. However, early ISO 14001 adopters often do not have this external knowledge available to them to help guide their implementation. Instead, they have to rely more on their internal knowledge to guide their "exploitation" (i.e. extracting benefits) of the "newly acquired knowledge" (i.e. ISO 14001) (Cohen and Levinthal, 1989). Early implementers with little prior related knowledge (low absorptive capacity) might have to spend more time and resources on the implementation because of their lack of knowledge and experience. Without prior expertise or knowledge, they are more likely to encounter problems in extracting the performance benefits out of their early mover strategy. As a result, firms with limited absorptive capacity may take a longer time or have difficulties to realize the benefits of ISO 14001, which renders the early mover strategy less effective. On the other hand, firms with high exploitation-based absorptive capacity can better resolve issues encountered during the implementation process, which in turn results in high performance benefits. As Lissenden (1999) noted: "... With this increased knowledge base of the common elements [of ISO 9001], the length of the registration process may be significantly reduced, and the benefits [of ISO 14001] may be realized much earlier". In other words, the exploitation-based absorptive

\footnotetext{
${ }^{3}$ http://www.epa.gov/sectors/sectorinfo/sectorprofiles/chemical/ems.html.
} 


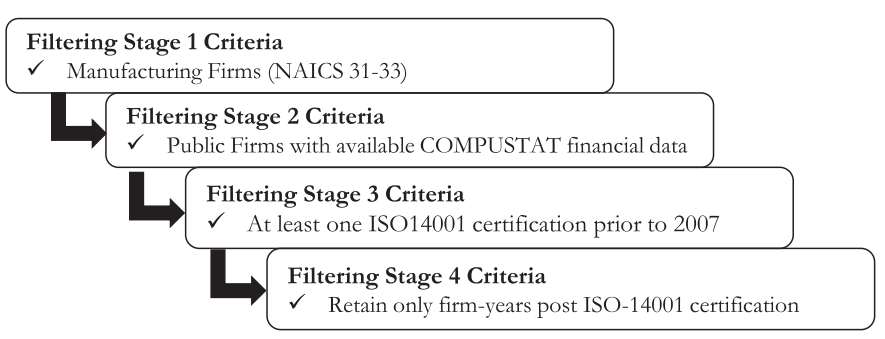

Fig. 3. Sampling procedure.

capacity helps firms exploit newly acquired knowledge, by leveraging existing competencies (Zahra and George, 2002). Often the same group of experts that led the ISO 9001 implementation also lead ISO 14001 implementation because of their familiarity and knowledge of the standard ${ }^{4}$. As a result, organizations that have more experience in ISO 9001 build significant knowledge repositories in different forms (e.g. employees, systems and processes). This cumulative knowledge provides the absorptive capacity a firm can then leverage (Zahra and George, 2002) to exploit new knowledge in the form of ISO 14001. The similarity between ISO 9001 and ISO 14001 further helps firms with such capacity exploit the benefits of ISO 14001 more effectively (Corbett and Kirsch, 2001). Collectively this suggests the following hypothesis.

Hypothesis 3. (H3): Exploitation-based absorptive capacity from prior ISO 9001 experience positively moderates the relationship between the timing of ISO 14001 implementation and firm performance.

\section{Research methodology}

\subsection{Data and sample}

The data come from two main sources. The ISO certification data comes from QSU Publishing Company and the financial data comes from COMPUSTAT. Fig. 3 shows the procedure used to collect the data. The data collection begins by filtering out publically traded manufacturing firms (NAICS codes 31-33), which resulted in an initial sample of 135 firms with 1356 firm-years of data spanning 12 years (1995-2007). We selected public firms since they make financial information public; and targeted manufacturing industries (NAICS 31-33) since they have higher intensity of ISO certification. This approach is consistent with the sampling procedure used by Corbett et al. (2005). Next, we only selected firms with at least one ISO 14001 certification during the 12 years (1995-2007), which reduced the sample to 101 firms. Collecting data this way helps evaluate the performance implications of relative timing of ISO 14001 implementation. Finally, we only retained firm-years of data after the first ISO 14001 certification had occurred for each firm. This reduced our final sample to 101 firms with 645 firm-years of data. This process ensured that we compare performance of those firms that implemented ISO 14001, although in different years. This is important since it allows us to investigate the timing effect of ISO 14001 implementation, without confounding with the event

\footnotetext{
4 As one reviewer pointed out “... also, firms actually keep repositories of these processes, they codify them in hand books and reports, these reports are shared and form the basis for the next team in the next department. Often they are shared on intranets. Firms train and employ process coaches, internal or external. These experts are certified as well, not unlike the different belts of six-sigma and carry knowledge from certification to certification. Often the same people that implemented ISO 9001 implemented ISO 14001 not because they are sustainability experts but because they are management standard experts." We thank the reviewer for suggesting this idea. We also verified this with other practitioners involved in the implementation process.
}

of implementing ISO 14001. Since, we consider firm-years after ISO 14001 implementation, any variance in performance should be due to factors (timing being of primary interest) beyond the implementation itself. In this respect, our study differs from previous studies which compare adopters to non-adopters. Furthermore, it allows examination of the moderating factors that strengthen (or weaken) the impact of ISO 14001 implementation timing. The final sample consists of firms from five industry sectors-Paper Manufacturing (NAICS $=322$ ), Chemical Manufacturing (NAICS $=325$ ), Machinery Manufacturing (NAICS =333), Computer and Electronic Manufacturing (NAICS = 334), Transportation Equipment Manufacturing (NAICS = 336). Table 1 provides the descriptive statistics.

One data collection challenge is matching facility-level ISO certifications with firm-level performance. The ISO certification database do not provide specific company information like the ticker symbol, which creates some challenges in matching the data. However, using available public databases such as ORBIS and Hoover's helps confirm whether a particular certified facility belongs to a parent public firm. Coding errors could happen due to a firm being listed in the ISO certification database with a slightly different name than the one used in COMPUSTAT. To eliminate such errors, one of the co-authors coded the data, which was then verified by another co-author for any errors. The verification resulted in making corrections for 27 firm-years of the data, which translates into an error rate of less than $3.5 \%$ of the final sample. Hence, we are confident that the final data is appropriate for conducting reliable analyses.

\subsection{Measures}

\subsubsection{Firm performance}

We operationalize firm performance using measures of firm profitability. Scholars in accounting have argued that the value of a business is a function of the "excess returns" i.e. profits that it generates from its investments (Damodaran, 2012). Return-on-assets (ROA), return-on-investments (ROI), and return-on-sales (ROS) are three well established measures of firm profitability. ROA measures profitability relative to the total assets, and measures how efficient the firm's assets generate earnings. This is a relatively stable profitability metric (Barber and Lyon, 1996). ROI measures a firm's ability to generate returns on the capital invested. Research shows that this metric provides valid estimates of unsystematic or firm-specific effects (Jacobson, 1987). Finally, ROS, a measure of firm profitability relative to its sales, can avoid estimation problems related to inter-firm differences in accounting techniques (Michael Geringer et al., 1989). In addition, one objective of ISO standards is to promote trade across the supply chain by streamlining the exchanged processes (Hufbauer et al., 2002), ISO standard should affect ROS. Taken together, ROA, ROS and ROI together provide good overall estimate of firm performance associated with ISO certifications.

\subsubsection{ISO 14001 relative timing}

This variable measures how early a firm first adopts ISO 14001 relative to their industry peers (at 3-digit NAICS level). We measure an organization's implementation timing based on the time when they received their first ISO 14001 certification for a facility within their organization relative to the competition. Since adoption decision is often at the firm level and standard implementation is at the facility level, the first certification reflects how quickly the firm is implementing ISO 14001 relative to their industry. For example, the average ISO 14001 certification year for the Computer \& Electronic Manufacturing industry (NAICS = 334) was 2001. Compared to the industry rivals, Xilinx Inc. received its first certification in 2004 for its facility in San Jose, CA. As a result, Xilinx Inc. has an ISO 14001 Relative Timing score of -3 (three years behind 
Table 1

Descriptive statistics for the final sample make-up.

\begin{tabular}{|c|c|c|c|c|c|c|c|c|}
\hline NAICS 3-digit & Industry description & Rival firms & Firm-years (N) & ROA (\%) & ROI (\%) & $\operatorname{ROS}(\%)$ & $\begin{array}{l}\text { Revenues } \\
\text { (million \$) }\end{array}$ & $\begin{array}{l}\text { ISO9001 } \\
\text { certificates (\#) }\end{array}$ \\
\hline 322 & Paper manufacturing & 7 & 42 & 5.7548 & 11.5187 & 16.7596 & $12,901.04$ & 24.30952 \\
\hline 325 & Chemical manufacturing & 19 & 122 & 4.5929 & 11.548 & 21.129 & $15,192.7$ & 36.51815 \\
\hline 333 & Machinery manufacturing & 12 & 73 & 6.3749 & 12.5634 & 18.5759 & 6765.57 & 24.91781 \\
\hline 334 & Computer \& electronic product manufacturing & 41 & 258 & 1.1691 & 3.8311 & 15.0624 & 9541.34 & 26.3351 \\
\hline \multirow[t]{2}{*}{336} & Transportation equipment manufacturing & 22 & 150 & 1.2847 & -1.6665 & 12.3174 & 33121.61 & 65.75301 \\
\hline & Total/average & 101 & 645 & 3.83528 & 7.55894 & 16.76886 & $15,504.452$ & 35.566718 \\
\hline
\end{tabular}

industry peers). A similar approach has been followed by prior studies examining the effect of facility-level variable on firmlevel outcomes (Corbett et al., 2005; Docking and Dowen, 1999; Simmons and White, 1999) $)^{5}$. This general approach has also been used in the management literature to study competitive dynamics (e.g. Chen, 1996).

\subsubsection{Moderating variables}

4.2.3.1. Competitive intensity. We use the well-established inverse of Herfindahl-Hirschman Index (HHI) to measure competitive intensity (i.e. Competition) (Derfus et al., 2008; Dess and Beard, 1984). $\mathrm{HHI}$ is defined as $\mathrm{HHI}_{i}=\sum_{k=1}^{n_{i}} S_{k i}^{2}$, where $S_{\mathrm{ki}}$ is the market share of firm $k$ and $n_{i}$ is the number of firms in industry $i$. A firm's market share is calculated as the ratio of its revenue to the sum of the revenue of all firms in the same industry level. HHI is a measure of industry concentration. The more competitors there are in the industry, the less concentrate the industry, the more intense the competitive environment.

4.2.3.2. Absorptive capacity. Zahra and George (2002) recommend measuring the 'intermediate outputs' such as the 'number of patents' to measure the exploitation dimension of absorptive capacity (p. 199). The exploitation dimension of absorptive capacity comes from a firm's existing stock of related knowledge, which is learned from prior experience (Cohen and Levinthal, 1990; Kantor and Zangwill, 1991). We measure the exploitation-based absorptive capacity as a firm's Cumulative ISO 9001 Certifications in a given year across all facilities (Benner and Tushman, 2002) and normalized by the firm's annual revenue. Recall that a firm's facilities need to go through an auditing process for implementation (firsttime certification) and have to get recertified every three years (re-certifications) to maintain their ISO 9001 certification. Experience and knowledge about standard implementation and usage is obtained as the by-product of practicing the standard. As a result, the accumulated number of certifications firms obtain represents the overall experience the firm acquired from using the standard. That is, a firm's overall level of exploitation-based absorptive capacity is the accumulated knowledge from the overall experience of using the standard across all their facilities. Prior literature has used similar volume based metrics to measure absorptive capacity such as (i) investments in science and technology (Mowery and Oxley, 1995) (ii) R\&D Investment (Cohen and Levinthal, 1990) (iii) number of doctorates/scientists (Veugelers, 1997) and (iv) more recently, number of patents (Vasudeva and Anand, 2011). In addition, since Cumulative ISO 9001 Certifications are past events, related practices

\footnotetext{
${ }^{5}$ In line with these studies, we expect that the effects of ISO 14001 Relative Timing (where implementation occurs at the facility-level) are observed at the firm-level performance. We believe this is the best approach possible to capture the timing of the initiation of new standards implementation at the firm-level. Furthermore, we concur with the logic provided by Corbett et al. (2005): "For small firms with a single site, the disconnect between site-level certifications and firm-level performance is not a major concern, while for large firms with many sites, this disconnect makes our tests more conservative: if the sample contains many multisite firms with only one certified site, any effects of certification must be strong in order to be detected."
}

and longitudinal, this measure better captures Cohen and Levinthal (1990)'s general notion that absorptive capacity is developmental, lagged, and path dependent.

4.2.3.3. Control variables. Consistent with prior related research (Corbett et al., 2005; Derfus et al., 2008; King et al., 2005), we control for several firm- and industry-level variables to capture the unobserved effects of firm-level resources that could affect firm performance. Since all our models predict future performance $(T+1$ and $T+2)$, we control for current firm performance $\left(D V_{T}\right)$ in order to examine the effect of hypothesized variables over and above the carry-over effect of existing firm performance (Baum and Wally, 2003; King and Lenox, 2002). Past values of the DV can be one of strongest control variable. Seminal works have shown that controlling for past performance can account for substantial portion of heterogeneity (Greene, 2003; Maddala, 1983; Wooldridge, 2010) at the industry level (e.g. accounting practices, regulation) and possible unobservable firm-specific characteristics (e.g. hierarchy, organizational structure). The analysis also includes the following firm-level control variables: firm size, capital intensity, R\&D intensity and also market value. Firm size is measured as the logarithm of employees. Firm's Capital intensity is measured as the ratio of assets by revenues for each firm-year. Firm's $R \mathcal{E} D$ intensity is measured as the ratio of annual R\&D investments by revenues for each firmyear. Tobin's $Q$ is used as a measure of firm's Market Value (Chung and Pruitt, 1994). Further, since the effect of ISO 14001 is largely on organizational processes, we used the Product Quality rating of each firm-year to control for any variation in performance attributable to the firm's products. This rating is obtained from the KLD database (Waddock and Graves, 1997), which assesses the performance of a firm's products using KLD's proprietary system.

To capture the unobserved industry-level effects, we control for additional industry-level variables following previous research (Dess and Beard, 1984). Industry growth or Munificence is measured as the sales growth over the previous five years. Industry volatility or Dynamism is measured as the average rate of sales change over the past five years. Year and industry dummies are also included to control for time-invariant industry-specific effects and year specific effects.

\subsection{Econometric modeling approach}

Table 2 gives summary statistics and correlations for the variables. The analyses began with the OLS regression approach followed by an analysis of residuals. A Breusch-Pagan/Cook-Weisberg test $(p<0.001)$ indicates problems with heteroskedasticity in the models. One option would be to use OLS regression with Huber/White (robust) standards errors. An alternate option is to use panel-fixed effects models. However, in this context the ISO 14001 Relative Timing does not necessarily update every year, but only in years when relative implementation timing of a company increased or decreased compared to its industry rivals. In such cases, using panel fixed effects would lead to multiple lost observations. Yet another option is to use the generalized least squares (GLS) estimator. We use the GLS approach for two reasons. First, 


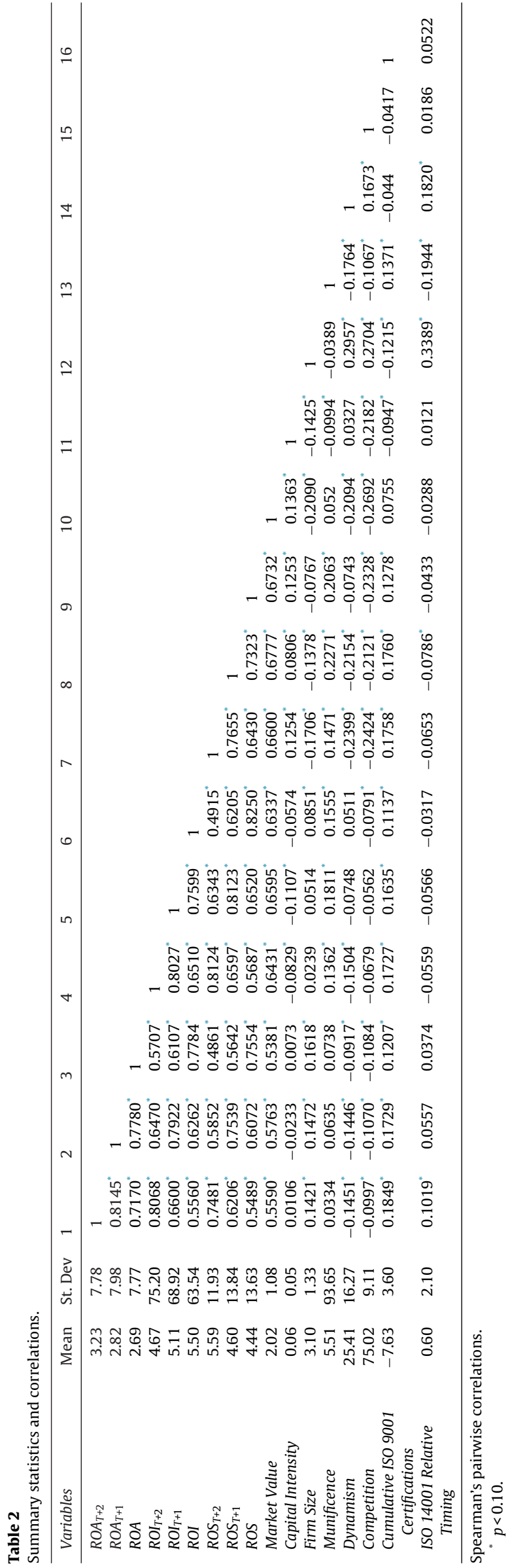

GLS accounts for the presence of severe heteroskedasticity across unbalanced panels in our data. Second, GLS estimation is also considered appropriate given that our models are sequentially (but not strictly) exogenous and accommodate for lagged dependent variables (Gedajlovic and Shapiro, 2002; Zhang and Rajagopalan, 2010). We therefore report all our results using the panel GLS estimation technique. For robustness, we specify a heteroskedastic error structure across panels and allowed serial (AR1) correlation within panels. We develop models to estimate the impact on future firm performance in line with King and Lenox (2002). All independent and control measures are standardized to improve interpretability and to avoid problems with collinearity.

Subgroup analysis and interaction analysis are the two methods commonly used to test for a moderating effect (Venkatraman, 1989). Researchers argue that subgroup analysis is more appropriate for testing the "strength" of moderation, which indicates the effects of certain factors differ across different environments (Arnold, 1982). In contrast, interaction analysis is more appropriate if the hypothesis reflects the "form" of moderation, which indicates that an outcome is jointly determined by the interaction of predictor and moderator (Venkatraman, 1989).

We predicted that Competition, a variable that reflects the level of competitive intensity of the business environment, moderates the relationship between ISO 14001 Relative Timing and firm performance. Here, the intention is to test the "strength" of moderation, which indicates that the effects of certain factors differ across different environments. In the analysis of strategy-performance relationship, Prescott (1986) concluded that when moderating the role of contextual variable one should follow a strength rather than form relationship. Hence, we conduct a subsample analyses, using two groups based on the level of Competition. For this purpose, we remove a portion of the observations around the median value and use the remaining observations to create polar groups (: p. 871). To achieve greater separation between firms facing higher versus lower levels of competition, we dropped the observations between the 45th and 55th percentile for Competition. Robustness tests show that changing the percentile criteria to achieve a wider or tighter spread did not affect the results. We report the results for the subsamples below the 45th percentile (Low Competition) and 55th percentile (High Competition).

We also predicted that absorptive capacity will positively moderate the relationship between ISO 14001 Relative Timing and firm performance. Here, the interest is in examining the "form" of moderation i.e. how absorptive capacity (generated through Cumulative ISO 9001 Certifications) and ISO 14001 Relative Timing jointly affect performance. Hence, we use interaction effects to test the hypothesis. The analyses use the STATA V13.1 software. The full model for estimating future performance can be written as the following equation:

$$
\begin{aligned}
\mathrm{DV}_{T+K}= & \gamma_{0}+\gamma_{i} I_{i}+\gamma_{j} Y_{j}+\gamma_{1} \mathrm{DV}_{T}+\gamma_{2}{\text { Market } \text { Value }_{T}} \\
& +\gamma_{3} \text { Capital Intensity }_{T}+\gamma_{4} \text { R\&D Intensity } \\
& +\gamma_{5} \text { Product Quality }_{T}+\gamma_{6} \text { Firm Size }_{T}+\gamma_{7} \text { Munificence }_{T} \\
& +\gamma_{8} \text { Dynamism }_{T}+\gamma_{9} \text { Competition }_{T} \\
& +\gamma_{10} \text { Cumulative ISO9001 Certifications }_{T} \\
& +\gamma_{11} \text { ISO14001 Relative Ti min }_{T}
\end{aligned}
$$

where $I_{i}$ and $Y_{j}$ represent industry and year dummies, respectively, and $k=1,2$ for subsequent year's firm performance. $D V$ represents the firm performance metric-ROA, ROI or ROS. To test the moderating effects of Competition, we conduct subsample analysis using 
Table 3

The effect of ISO 14001 timing on firm performance.

\begin{tabular}{|c|c|c|c|c|c|c|c|c|c|c|c|c|}
\hline Variables & Model 1 & Model 2 & Model 3 & Model 4 & Model 5 & Model 6 & Model 7 & Model 8 & Model 9 & Model 10 & Model 11 & Model 12 \\
\hline & $\mathrm{ROA}_{T+1}$ & $\mathrm{ROA}_{T+1}$ & $\mathrm{ROA}_{T+2}$ & $\mathrm{ROA}_{T+2}$ & $\operatorname{ROS}_{T+1}$ & $\operatorname{ROS}_{T+1}$ & $\operatorname{ROS}_{T+2}$ & $\operatorname{ROS}_{T+2}$ & $\mathrm{ROI}_{T+1}$ & $\mathrm{ROI}_{T+1}$ & $\mathrm{ROI}_{T+2}$ & $\mathrm{ROI}_{T+2}$ \\
\hline \multirow[t]{2}{*}{$D V_{T}$} & $0.91^{* * * *}$ & $0.90^{* * * *}$ & $0.71^{* * * *}$ & $0.70^{* * * *}$ & $0.77^{* * * *}$ & $0.77^{* * * *}$ & $0.35^{* * *}$ & $0.34^{* * *}$ & $0.79^{* * * *}$ & $0.79^{* * * *}$ & $0.37^{* * *}$ & $0.31^{* * * *}$ \\
\hline & $(0.02)$ & $(0.02)$ & $(0.03)$ & $(0.03)$ & $(0.02)$ & $(0.02)$ & $(0.04)$ & $(0.04)$ & $(0.04)$ & $(0.05)$ & $(0.06)$ & $(0.07)$ \\
\hline \multirow[t]{2}{*}{ Market Value } & $0.48^{* * *}$ & $0.51^{* * * *}$ & $1.19^{* * * *}$ & $1.21^{* * * *}$ & $1.11^{* * * *}$ & $1.10^{* * * *}$ & $2.78^{* * * *}$ & $2.65^{* * * *}$ & $1.96^{* * *}$ & $1.89^{* * *}$ & $4.88^{* * * *}$ & $3.83^{* * *}$ \\
\hline & $(0.10)$ & $(0.10)$ & $(0.15)$ & $(0.14)$ & $(0.17)$ & $(0.17)$ & $(0.28)$ & $(0.27)$ & $(0.42)$ & $(0.43)$ & $(0.58)$ & $(0.78)$ \\
\hline \multirow[t]{2}{*}{ Capital Intensity } & 1.42 & $2.97^{*}$ & $6.21^{*}$ & $8.14^{* *}$ & $7.35^{*}$ & $8.38^{* *}$ & $19.03^{* * *}$ & $23.11^{* * *}$ & $-22.45^{* *}$ & $-21.44^{*}$ & $-48.42^{* * *}$ & $-37.57^{*}$ \\
\hline & $(1.70)$ & $(1.66)$ & $(3.26)$ & (3.19) & $(3.90)$ & $(4.08)$ & $(6.40)$ & $(6.66)$ & $(11.03)$ & $(11.32)$ & $(15.60)$ & (19.27) \\
\hline \multirow[t]{2}{*}{ RED Intensity } & 0.04 & 0.02 & 0.02 & 0.01 & 0.26 & 0.24 & -0.03 & -0.08 & 0.28 & 0.23 & 0.41 & 0.13 \\
\hline & $(0.03)$ & $(0.03)$ & $(0.03)$ & $(0.03)$ & $(0.45)$ & $(0.46)$ & $(0.44)$ & $(0.45)$ & $(0.24)$ & $(0.24)$ & $(0.26)$ & $(0.44)$ \\
\hline \multirow[t]{2}{*}{ Product Quality } & -0.03 & -0.01 & -0.09 & -0.09 & -0.20 & -0.27 & -0.37 & -0.51 & 0.63 & 0.31 & $1.89^{* \prime}$ & 1.09 \\
\hline & $(0.15)$ & $(0.14)$ & $(0.28)$ & $(0.28)$ & $(0.25)$ & $(0.25)$ & $(0.36)$ & $(0.38)$ & $(0.85)$ & $(0.85)$ & $(1.08)$ & $(1.60)$ \\
\hline \multirow[t]{2}{*}{ Firm Size } & $0.14^{* * * *}$ & $0.11^{* *}$ & $0.38^{* * * *}$ & $0.32^{* * * *}$ & 0.09 & 0.08 & 0.17 & 0.14 & -0.13 & -0.13 & 0.24 & 0.07 \\
\hline & $(0.05)$ & $(0.05)$ & $(0.07)$ & $(0.08)$ & $(0.09)$ & $(0.10)$ & $(0.15)$ & $(0.16)$ & $(0.30)$ & $(0.30)$ & $(0.38)$ & $(0.58)$ \\
\hline \multirow[t]{2}{*}{ Munificence } & -0.00 & -0.00 & -0.00 & -0.00 & $-0.01^{* * *}$ & $-0.01^{* * *}$ & $-0.02^{* * *}$ & $-0.02^{* * *}$ & -0.02 & -0.02 & -0.02 & -0.02 \\
\hline & $(0.00)$ & $(0.00)$ & $(0.00)$ & $(0.00)$ & $(0.00)$ & $(0.00)$ & $(0.01)$ & $(0.01)$ & $(0.01)$ & $(0.01)$ & $(0.02)$ & $(0.02)$ \\
\hline \multirow[t]{2}{*}{ Dynamism } & -0.02 & -0.02 & -0.01 & -0.02 & -0.02 & -0.02 & 0.00 & 0.01 & -0.02 & -0.04 & -0.02 & -0.06 \\
\hline & $(0.01)$ & $(0.01)$ & $(0.02)$ & $(0.02)$ & $(0.02)$ & $(0.02)$ & $(0.03)$ & $(0.03)$ & $(0.07)$ & $(0.06)$ & $(0.07)$ & $(0.09)$ \\
\hline \multirow[t]{2}{*}{ Competition } & -0.01 & -0.01 & -0.01 & -0.01 & -0.01 & -0.00 & -0.04 & -0.03 & $0.19^{*}$ & 0.17 & $0.44^{* * *}$ & 0.33 \\
\hline & $(0.02)$ & $(0.02)$ & $(0.02)$ & $(0.02)$ & $(0.03)$ & $(0.03)$ & $(0.05)$ & $(0.05)$ & $(0.10)$ & $(0.11)$ & $(0.14)$ & $(0.20)$ \\
\hline Cumulative ISO 9001 & $0.33^{* * * 3}$ & $0.26^{* * * *}$ & $0.66^{* * *}$ & $0.60^{* * * *}$ & $0.53^{* * * *}$ & $0.52^{* * * *}$ & $0.50^{* *}$ & $0.50^{* *}$ & $0.77^{*}$ & 0.68 & $1.92^{* * * *}$ & 1.26 \\
\hline Certifications & $(0.08)$ & $(0.08)$ & $(0.11)$ & $(0.12)$ & $(0.16)$ & $(0.17)$ & $(0.23)$ & $(0.25)$ & $(0.42)$ & $(0.45)$ & $(0.46)$ & $(0.79)$ \\
\hline ISO 14001 Relative & & $0.30^{* * * *}$ & & $0.39^{* * * *}$ & & 0.15 & & $0.47^{* *}$ & & 0.32 & & 0.95 \\
\hline Timing & & $(0.07)$ & & $(0.12)$ & & $(0.13)$ & & $(0.20)$ & & $(0.41)$ & & $(0.80)$ \\
\hline Observations & 543 & 543 & 441 & 441 & 543 & 543 & 441 & 441 & 543 & 543 & 441 & 441 \\
\hline Wald's chi2 & 7471.47 & 7434.19 & 3758.69 & 3011.23 & 7048.68 & $12,299.15$ & 1087.79 & 952.59 & 2511.73 & 2449.98 & 474.57 & 484.61 \\
\hline
\end{tabular}

* $p<0.1$; Industry and year dummies included in all models; Intercept values not shown; All Wald's Statistics were significant at $p<0.001$; Heteroskedastic Panel structure used; AR1 serial correlation assumed within panels with a Nagar autocorrelation parameter.

${ }^{* *} p<0.05$.

*** $p<0.01$.

a model similar to (1). To test moderating effects of Cumulative ISO 9001 Certifications, we use the following equation:

$$
\begin{aligned}
\text { DV }_{T+K}= & \gamma_{0}+\gamma_{i} I_{i}+\gamma_{j} Y_{j}+\gamma_{1} \text { DV }_{T}+\gamma_{2} \text { Market Value }_{T} \\
& +\gamma_{3} \text { Capital Intensity }_{T}+\gamma_{4} \text { R\&D Intensity }_{T} \\
& +\gamma_{5} \text { Product Quality }_{T}+\gamma_{6} \text { Firm Size }_{T}+\gamma_{7} \text { Munificence }_{T} \\
& +\gamma_{8} \text { Dynamism }_{T}+\gamma_{9} \text { Competition }_{T} \\
& +\gamma_{10} \text { Cumulative ISO9001 Certifications }_{T} \\
& +\gamma_{11} \text { ISO14001 Relative Ti min }_{T} \\
& +\gamma_{12} \text { Cumulative ISO9001 Certifications }_{T} \\
& \times \text { ISO14001 Relative Ti min }_{T}
\end{aligned}
$$

\section{Results}

\subsection{Main effects of ISO 14001 timing on firm performance}

Table 3 reports the results for testing the main effect of ISO 14001 Relative Timing on firm performance (H3). The results indicate that ISO 14001 Relative Timing has a positive relationship with $\mathrm{ROA}_{T+1}$ (Model 2, $\beta=0.30 ; p<0.01$ ) and $\mathrm{ROA}_{T+2}$ (Model 4, $\beta=0.39$; $p<0.01$ ). Furthermore, ISO 14001 Relative Timing has a positive relationship with $\operatorname{ROS}_{T+2}$ (Model 8, $\beta=0.47 ; p<0.05$ ). Finally, we do not find a significant relationship between ISO 14001 Relative Timing and $\mathrm{ROI}_{T+1}$, although the coefficients are positive. On average, the effect sizes appear to become stronger for the models with two-year leading performance as the dependent variable, which is consistent with the findings in Corbett et al. (2005). Overall, these results provide strong support for $\mathrm{H} 1$, with respect to ROA and ROS but not for ROI.

\subsection{Moderating "strength" effects of competition}

Table 4 shows the results for the moderating effects of Competition. We examine the "strength" of moderation, to understand how the main effects of ISO 14001 Relative Timing increase/decrease across different competitive environments. ISO 14001 Relative Timing has no significant relationship with ROA or ROS under low competition. Furthermore, ISO 14001 Relative Timing has a negative relationship with $\mathrm{ROI}_{T+2}$ (Model 10, $\beta=-1.38 ; p<0.05$ ) under low competition. These results indicate that the importance of ISO 14001 Relative Timing diminishes under low competitive intensity.

Table 4 also gives the results under high competition. In contrast to low competition, ISO 14001 Relative Timing now significantly predicts future firm profitability. ISO 14001 Relative Timing has a strong positive relationship with $\mathrm{ROA}_{T+1}$ (Model 3, $\beta=0.39 ; p<0.01$ ) and $\mathrm{ROA}_{T+2}$ (Model 4, $\beta=0.75 ; p<0.01$ ) under high competition. ISO 14001 Relative Timing also has a strong positive relationship with $\operatorname{ROS}_{T+1}$ (Model 7, $\beta=0.29 ; p<0.05$ ) and $\operatorname{ROS}_{T+2}$ (Model 8, $\beta=0.77$; $p<0.01$ ). We do not find enough evidence that ISO 14001 Relative Timing is associated with ROI under high competition. Overall, we can confidently say that the effect of ISO 14001 Relative Timing dominates in high competition environments but does not have a major positive influence on firm performance under low competition. Hence, the benefits of being an early mover advantage only applies to highly competitive environments.

\subsection{Moderating "form" effects of cumulative ISO 9001 certifications}

Table 5 shows the results for the moderating effects of Cumulative ISO 9001 Certifications. As discussed earlier, we examine the "form" of moderation, to understand how Cumulative ISO $9001 \mathrm{Cer}$ tifications and ISO 14001 Relative Timing jointly affect future firm performance. Table 5 gives the models based on interaction effects. The interaction term has a positive and significant relationship with $\mathrm{ROA}_{T+1}$ (Model 1, $\beta=0.28 ; p<0.01$ ) and $\mathrm{ROA}_{T+2}$ (Model 2, $\beta=0.65$; $p<0.01)$. The interaction term also has a positive and significant relationship with $\mathrm{ROS}_{T+1}$ (Model 3, $\beta=0.38 ; p<0.10$ ) and $\operatorname{ROS}_{T+2}$ (Model $4, \beta=0.90 ; p<0.05$ ). Once again, we do not find a significant effect for ROI, although the coefficients are in the expected 
Table 4

Moderating "strength" effects of competition.

\begin{tabular}{|c|c|c|c|c|c|c|c|c|c|c|c|c|}
\hline \multirow[t]{2}{*}{ Variables } & \multicolumn{2}{|c|}{ Low competition } & \multicolumn{2}{|c|}{ High competition } & \multicolumn{2}{|c|}{ Low competition } & \multicolumn{2}{|c|}{ High competition } & \multicolumn{2}{|c|}{ Low competition } & \multicolumn{2}{|c|}{ High competition } \\
\hline & Model 1 & Model 2 & Model 3 & Model 4 & Model 5 & Model 6 & Model 7 & Model 8 & Model 9 & Model 10 & Model 11 & Model 12 \\
\hline & $\mathrm{ROA}_{T+1}$ & $\mathrm{ROA}_{T+2}$ & $\mathrm{ROA}_{T+1}$ & $\mathrm{ROA}_{T+2}$ & $\operatorname{ROS}_{T+1}$ & $\operatorname{ROS}_{T+2}$ & $\operatorname{ROS}_{T+1}$ & $\operatorname{ROS}_{T+2}$ & $\mathrm{ROI}_{T+1}$ & $\mathrm{ROI}_{T+2}$ & $\mathrm{ROI}_{T+1}$ & $\mathrm{ROI}_{T+2}$ \\
\hline$D V_{T}$ & $\begin{array}{l}0.85^{* * *} \\
(0.04)\end{array}$ & $\begin{array}{l}0.47^{* * *} \\
(0.05)\end{array}$ & $\begin{array}{l}0.93^{* * *} \\
(0.02)\end{array}$ & $\begin{array}{l}0.75^{* * *} \\
(0.04)\end{array}$ & $\begin{array}{l}0.68^{* * *} \\
(0.04)\end{array}$ & $\begin{array}{l}0.28^{* * *} \\
(0.04)\end{array}$ & $\begin{array}{l}0.83^{* * *} \\
(0.02)\end{array}$ & $\begin{array}{l}0.64^{* * *} \\
(0.06)\end{array}$ & $\begin{array}{l}0.65^{* * *} \\
(0.06)\end{array}$ & $\begin{array}{l}0.18^{* * *} \\
(0.06)\end{array}$ & $\begin{array}{l}1.13^{* * *} \\
(0.05)\end{array}$ & $\begin{array}{l}0.60^{* * *} \\
(0.15)\end{array}$ \\
\hline Market Value & $\begin{array}{l}0.50^{* *} \\
(0.20)\end{array}$ & $\begin{array}{l}1.04^{* * *} \\
(0.25)\end{array}$ & $\begin{array}{l}0.16 \\
(0.12)\end{array}$ & $\begin{array}{l}0.95^{* * *} \\
(0.23)\end{array}$ & $\begin{array}{l}1.31^{* * *} \\
(0.30)\end{array}$ & $\begin{array}{l}2.43^{* * * *} \\
(0.35)\end{array}$ & $\begin{array}{l}0.68^{* * *} \\
(0.21)\end{array}$ & $\begin{array}{l}1.12^{* * * *} \\
(0.40)\end{array}$ & $\begin{array}{l}1.86^{* * *} \\
(0.38)\end{array}$ & $\begin{array}{l}2.89^{* * *} \\
(0.55)\end{array}$ & $\begin{array}{l}-0.96 \\
(0.79)\end{array}$ & $\begin{array}{l}3.43^{* *} \\
(1.53)\end{array}$ \\
\hline Capital Intensity & $\begin{array}{l}3.68 \\
(3.30)\end{array}$ & $\begin{array}{l}26.30^{* * *} \\
(5.76)\end{array}$ & $\begin{array}{l}-0.38 \\
(3.67)\end{array}$ & $\begin{array}{l}-5.20 \\
(7.14)\end{array}$ & $\begin{array}{l}13.37^{* *} \\
(6.20)\end{array}$ & $\begin{array}{l}45.14^{* * * *} \\
(7.85)\end{array}$ & $\begin{array}{l}-14.41^{* *} \\
(6.88)\end{array}$ & $\begin{array}{l}-13.95 \\
(12.02)\end{array}$ & $\begin{array}{l}-5.46 \\
(6.81)\end{array}$ & $\begin{array}{l}18.35^{*} \\
(10.02)\end{array}$ & $\begin{array}{l}-85.94^{*} \\
(51.51)\end{array}$ & $\begin{array}{l}-151.2^{* *} \\
(69.76)\end{array}$ \\
\hline REDD Intensity & $\begin{array}{l}0.04 \\
(0.07)\end{array}$ & $\begin{array}{l}-0.04 \\
(0.11)\end{array}$ & $\begin{array}{l}1.03^{*} \\
(0.55)\end{array}$ & $\begin{array}{l}-0.19 \\
(1.09)\end{array}$ & $\begin{array}{l}-2.03^{* *} \\
(0.85)\end{array}$ & $\begin{array}{l}-0.37^{* * * *} \\
(0.11)\end{array}$ & $\begin{array}{l}-2.01^{* * *} \\
(0.91)\end{array}$ & $\begin{array}{l}-3.64 \\
(1.57)\end{array}$ & $\begin{array}{l}-0.63 \\
(0.43)\end{array}$ & $\begin{array}{l}0.01 \\
(0.10)\end{array}$ & $\begin{array}{l}-2.53 \\
(6.53)\end{array}$ & $\begin{array}{l}5.23 \\
(11.39)\end{array}$ \\
\hline Product Quality & $\begin{array}{l}-0.41 \\
(0.32)\end{array}$ & $\begin{array}{l}-0.76 \\
(0.52)\end{array}$ & $\begin{array}{l}0.04 \\
(0.15)\end{array}$ & $\begin{array}{l}-0.49 \\
(0.32)\end{array}$ & $\begin{array}{l}-0.56 \\
(0.43)\end{array}$ & $\begin{array}{l}-2.69^{* * *} \\
(0.79)\end{array}$ & $\begin{array}{l}-0.09 \\
(0.23)\end{array}$ & $\begin{array}{l}-0.42 \\
(0.40)\end{array}$ & $\begin{array}{l}0.57 \\
(0.62)\end{array}$ & $\begin{array}{l}-1.37 \\
(1.36)\end{array}$ & $\begin{array}{l}-0.64 \\
(2.03)\end{array}$ & $\begin{array}{l}-1.30 \\
(2.84)\end{array}$ \\
\hline Firm Size & $\begin{array}{l}0.14 \\
(0.11)\end{array}$ & $\begin{array}{l}0.84^{* * *} \\
(0.20)\end{array}$ & $\begin{array}{l}0.03 \\
(0.07)\end{array}$ & $\begin{array}{l}0.23 \\
(0.14)\end{array}$ & $\begin{array}{l}0.25 \\
(0.22)\end{array}$ & $\begin{array}{l}0.78^{* *} \\
(0.30)\end{array}$ & $\begin{array}{l}-0.41^{* * *} \\
(0.16)\end{array}$ & $\begin{array}{l}-0.85^{* * *} \\
(0.27)\end{array}$ & $\begin{array}{l}0.56^{* *} \\
(0.24)\end{array}$ & $\begin{array}{l}1.70^{* * *} \\
(0.35)\end{array}$ & $\begin{array}{l}-1.84^{* *} \\
(0.87)\end{array}$ & $\begin{array}{l}-1.94 \\
(1.37)\end{array}$ \\
\hline Munificence & $\begin{array}{l}-0.03 \\
(0.02)\end{array}$ & $\begin{array}{l}-0.08^{*} \\
(0.04)\end{array}$ & $\begin{array}{l}-0.00 \\
(0.00)\end{array}$ & $\begin{array}{l}-0.01 \\
(0.01)\end{array}$ & $\begin{array}{l}-0.03 \\
(0.03)\end{array}$ & $\begin{array}{l}-0.11^{* *} \\
(0.06)\end{array}$ & $\begin{array}{l}-0.01^{*} \\
(0.00)\end{array}$ & $\begin{array}{l}-0.01 \\
(0.01)\end{array}$ & $\begin{array}{l}-0.04 \\
(0.04)\end{array}$ & $\begin{array}{l}-0.08 \\
(0.06)\end{array}$ & $\begin{array}{l}-0.03 \\
(0.04)\end{array}$ & $\begin{array}{l}-0.04 \\
(0.05)\end{array}$ \\
\hline Dynamism & $\begin{array}{l}-0.02 \\
(0.04)\end{array}$ & $\begin{array}{l}-0.13^{* *} \\
(0.07)\end{array}$ & $\begin{array}{l}-0.06^{* *} \\
(0.03)\end{array}$ & $\begin{array}{l}-0.11^{*} \\
(0.06)\end{array}$ & $\begin{array}{l}0.07 \\
(0.07)\end{array}$ & $\begin{array}{l}-0.08 \\
(0.10)\end{array}$ & $\begin{array}{l}-0.09^{*} \\
(0.05)\end{array}$ & $\begin{array}{l}-0.11^{*} \\
(0.07)\end{array}$ & $\begin{array}{l}0.02 \\
(0.07)\end{array}$ & $\begin{array}{l}-0.08 \\
(0.12)\end{array}$ & $\begin{array}{l}-0.15 \\
(0.40)\end{array}$ & $\begin{array}{l}-0.28 \\
(0.52)\end{array}$ \\
\hline Cumulative ISO 9001 & $0.44^{* *}$ & $0.86^{* * *}$ & $0.44^{* * * *}$ & $0.90^{* * *}$ & $0.45^{*}$ & 0.24 & $0.54^{* *}$ & $0.93^{*}$ & $0.89^{* *}$ & $1.71^{* * *}$ & $2.57^{* *}$ & 2.31 \\
\hline Certifications & $(0.19)$ & $(0.23)$ & $(0.14)$ & $(0.24)$ & $(0.24)$ & $(0.24)$ & $(0.26)$ & $(0.54)$ & $(0.36)$ & $(0.37)$ & $(1.02)$ & $(1.98)$ \\
\hline $\begin{array}{l}\text { ISO } 14001 \text { Relative } \\
\text { Timing }\end{array}$ & $\begin{array}{l}-0.04 \\
(0.19)\end{array}$ & $\begin{array}{l}-0.20 \\
(0.28)\end{array}$ & $\begin{array}{l}0.39^{* * *} \\
(0.08)\end{array}$ & $\begin{array}{l}0.75^{* * *} \\
(0.18)\end{array}$ & $\begin{array}{l}0.17 \\
(0.28)\end{array}$ & $\begin{array}{l}0.19 \\
(0.44)\end{array}$ & $\begin{array}{l}0.29^{* *} \\
(0.14)\end{array}$ & $\begin{array}{l}0.77^{* * *} \\
(0.23)\end{array}$ & $\begin{array}{l}-0.35 \\
(0.39)\end{array}$ & $\begin{array}{l}-1.38^{* *} \\
(0.60)\end{array}$ & $\begin{array}{l}1.13 \\
(0.85)\end{array}$ & $\begin{array}{l}0.52 \\
(1.51)\end{array}$ \\
\hline Observations & 240 & 186 & 242 & 190 & 240 & 186 & 242 & 190 & 240 & 186 & 242 & 190 \\
\hline Wald's chi2 & 1828.88 & 547.53 & 5897.35 & 2593.55 & 1466.23 & 5034.53 & $10,393.5$ & 908.81 & 898.87 & 716.60 & 2619.47 & 140.20 \\
\hline
\end{tabular}

${ }^{*} p<0.1$; industry \& year dummies included in all models; intercept values not shown; All Wald's Statistics were significant at $p<0.001$; heteroskedastic panel structure used; AR1 serial correlation assumed within panels with a Nagar autocorrelation parameter.

*** $p<0.05$.

*** $p<0.01$.

direction. Overall, the results offer substantial evidence that Cumulative ISO 9001 Certifications and ISO 14001 Relative Timing jointly affect future firm performance.

Fig. 4 illustrates the interaction effects graphically. The graphs show that early adoption of ISO 14001 (i.e. a high ISO 14001 Relative
Timing) leads to more successful outcomes (i.e. higher firm performance) only when the firm has a larger stock of related knowledge (i.e. more Cumulative ISO 9001 Certifications). On the other hand, when the firm lacks the stock of prior ISO 9001 knowledge (i.e. fewer Cumulative ISO 9001 Certifications) it should avoid being an

Table 5

Moderating “form" effects of ISO 9001 cumulative certifications.

\begin{tabular}{|c|c|c|c|c|c|c|}
\hline Variables & Model 1 & Model 2 & Model 3 & Model 4 & Model 5 & Model 6 \\
\hline & $\mathrm{ROA}_{T+1}$ & $\mathrm{ROA}_{T+2}$ & $\operatorname{ROS}_{T+1}$ & $\operatorname{ROS}_{T+2}$ & $\mathrm{ROI}_{T+1}$ & $\mathrm{ROI}_{T+2}$ \\
\hline \multirow[t]{2}{*}{$D V_{T}$} & $0.90^{* * * *}$ & $0.69^{* * * *}$ & $0.76^{* * *}$ & $0.32^{* * *}$ & $0.78^{* * *}$ & $0.39^{* * *}$ \\
\hline & $(0.02)$ & $(0.03)$ & $(0.02)$ & $(0.04)$ & $(0.05)$ & $(0.06)$ \\
\hline \multirow[t]{2}{*}{ Market Value } & $0.54^{* * * *}$ & $1.34^{* * * *}$ & $1.13^{* * * *}$ & $2.79^{* * * *}$ & $1.93^{* * * *}$ & $4.72^{* * * *}$ \\
\hline & $(0.10)$ & $(0.16)$ & $(0.17)$ & $(0.27)$ & $(0.45)$ & $(0.63)$ \\
\hline \multirow[t]{2}{*}{ Capital Intensity } & 2.46 & $6.57^{* *}$ & $7.92^{*}$ & $19.64^{* * *}$ & $-20.53^{*}$ & $-53.97^{* * *}$ \\
\hline & (1.59) & $(2.95)$ & (4.09) & $(6.77)$ & $(11.33)$ & $(15.59)$ \\
\hline \multirow[t]{2}{*}{ RED Intensity } & 0.03 & 0.03 & 0.30 & -0.02 & 0.20 & 0.31 \\
\hline & $(0.03)$ & $(0.03)$ & $(0.46)$ & $(0.45)$ & $(0.24)$ & $(0.26)$ \\
\hline \multirow[t]{2}{*}{ Product Quality } & 0.02 & -0.15 & -0.27 & -0.43 & 0.27 & $1.81^{*}$ \\
\hline & $(0.14)$ & $(0.28)$ & $(0.25)$ & $(0.38)$ & $(0.84)$ & $(1.00)$ \\
\hline \multirow[t]{2}{*}{ Firm Size } & $0.11^{* *}$ & $0.37^{* * * *}$ & 0.08 & 0.17 & -0.19 & 0.06 \\
\hline & $(0.05)$ & $(0.09)$ & $(0.10)$ & $(0.16)$ & $(0.30)$ & $(0.38)$ \\
\hline \multirow[t]{2}{*}{ Munificence } & -0.00 & -0.00 & $-0.01^{* * *}$ & $-0.02^{* * *}$ & -0.02 & -0.01 \\
\hline & $(0.00)$ & $(0.00)$ & $(0.00)$ & $(0.01)$ & $(0.01)$ & $(0.02)$ \\
\hline \multirow[t]{2}{*}{ Dynamism } & -0.01 & -0.01 & -0.02 & 0.01 & -0.03 & -0.01 \\
\hline & $(0.01)$ & $(0.02)$ & $(0.02)$ & $(0.03)$ & $(0.06)$ & $(0.07)$ \\
\hline \multirow[t]{2}{*}{ Competition } & -0.01 & -0.02 & -0.00 & -0.03 & 0.16 & $0.46^{* * *}$ \\
\hline & $(0.02)$ & $(0.03)$ & $(0.03)$ & $(0.05)$ & $(0.11)$ & $(0.15)$ \\
\hline \multirow[t]{2}{*}{ Cumulative ISO 9001 Certifications } & $0.14^{*}$ & $0.19^{*}$ & $0.37^{* *}$ & 0.18 & 0.44 & 0.60 \\
\hline & $(0.08)$ & $(0.11)$ & $(0.19)$ & $(0.25)$ & $(0.61)$ & $(0.75)$ \\
\hline \multirow[t]{2}{*}{ ISO 14001 Relative Timing } & 0.10 & -0.00 & -0.16 & -0.24 & 0.13 & -1.35 \\
\hline & $(0.10)$ & $(0.16)$ & $(0.22)$ & $(0.34)$ & $(0.63)$ & $(0.89)$ \\
\hline Cumulative ISO 9001 Certifications $\times$ ISO & $0.28^{* * *}$ & $0.65^{* * *}$ & $0.38^{*}$ & $0.90^{* *}$ & 0.23 & 1.23 \\
\hline 14001 Relative Timing & $(0.10)$ & $(0.17)$ & $(0.22)$ & $(0.35)$ & $(0.68)$ & $(0.95)$ \\
\hline Observations & 543 & 441 & 543 & 441 & 543 & 441 \\
\hline Wald's chi2 & 7962.98 & 2639.34 & $11,278.06$ & 931.92 & 2459.78 & 420.23 \\
\hline
\end{tabular}

* $p<0.1$; industry \& year dummies included; intercept values not shown; all Wald's statistics were significant at $p<0.001$; heteroskedastic panel structure used; AR1 serial correlation assumed within panels with a Nagar autocorrelation parameter.

*** $p<0.05$.

*** $p<0.01$. 


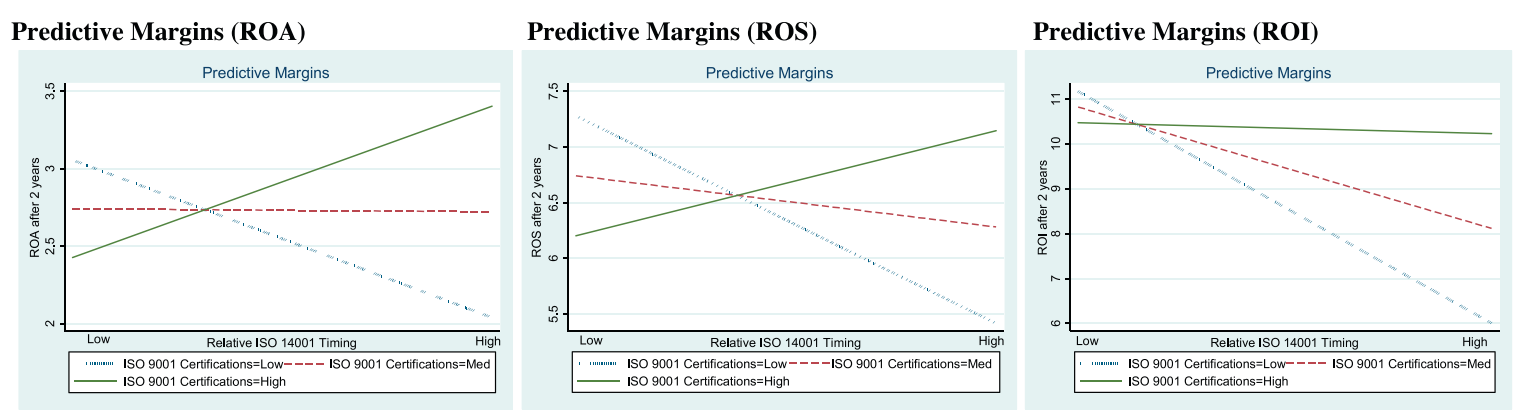

Fig. 4. Interaction plots for ISO 9001 cumulative certifications.

early adopter of ISO 14001. Under such circumstances, being a slow mover might actually be beneficial. However, being an early adopter of ISO 14001 when the firm lacks prior ISO 9001 experience actually leads to the worst performance outcomes (see Fig. 4). These effects are consistent across all three performance metrics, and suggest that firm's exploitation-based absorptive capacity is a boundary condition to gain an early-mover advantage. We discuss several implications of these results in Section 8.

\section{Robustness analysis and boundary conditions}

Our modeling approach has several built-in robustness checks. We use three different performance measures (ROA, ROI, ROS) for firm profitability to insure the robustness of the results. Further, we present the results for future performance in two time periods $(T+1, T+2)$. In addition, we controlled for lagged dependent variables in all our models, which can lead to problems with serial correlation across time periods. To address this issue, we accounted for a first degree autocorrelation process (AR1) using the Nagar autocorrelation parameter. Our results are sufficiently robust for the ROA and ROS measures of firm performance and provide partial support for ROI. In general the results show that the performance impact gets stronger at $T+2$, which is expected since the performance benefits from ISO implementation are only observed as organizational processes improve over time. Such delayed benefits are consistent with results obtained by Corbett et al. (2005). Below we address some additional concerns by conducting further robustness analysis.

\subsection{Endogeneity in the DVs}

Controlling for lagged dependent variables raises an issue of endogeneity. More specifically, $\mathrm{DV}_{T}$ which appears as a control variable in all our models could be correlated with the error term $\varepsilon_{t}$. To address this problem, Wooldridge (2010) recommends using subsequent lags of the dependent variable as instruments. This can be achieved by using a 2 stage least squares (2SLS) approach where $\mathrm{DV}_{T}$ is instrumented using $\mathrm{DV}_{T-1}$. The instrumented variable $\mathrm{DV}_{\text {TINSTRUMENTED }}$ is then used as a control variable in Eqs. (1) and (2) specified above. Table A1 in the Appendix reports estimation results for models which account for endogeneity using instrumented dependent variables $\mathrm{DV}_{T_{-} \text {INSTRUMENTED }}$ as controls. This approach did not significantly affect results.

\subsection{Alternate measures for key variables}

As an additional robustness check, we re-calculated the ISO 14001 Relative Timing variable by considering competition at a 2-digit NAICS level (not shown). This approach made the results weaker since the new ISO 14001 Relative Timing variable less accurately captured inter-firm competition within their particular industries. However, most of the findings did not qualitatively

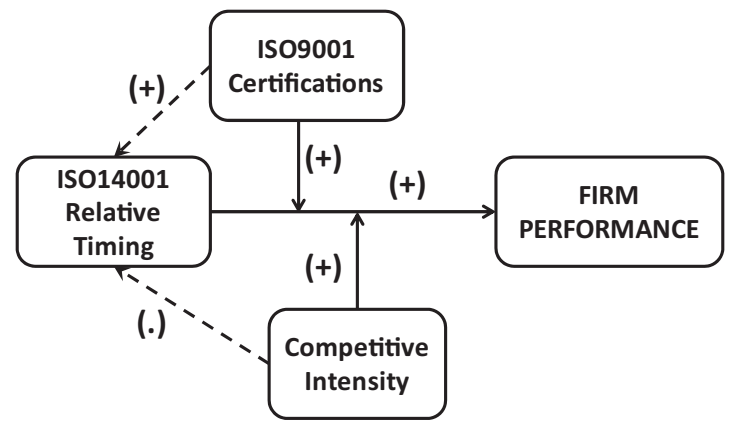

Fig. 5. Extension 1.

change. Further, it could be argued that a firm's ex ante stock of ISO 9001 certifications (i.e. cumulative ISO 9001 certifications at the time of first ISO 14001 certification) is what matters for the interaction effect with firm's timing of certification ${ }^{6}$. Hence, we created an alternate measure Cumulative ISO 9001 Certifications (ex ante), which only includes ISO 9001 certifications until the first ISO 14001 certification occurs for each firm. The results (Appendix 2) using this measure are consistent with our previous findings. Finally, to create high and low industry competition subsamples in the analysis, we had dropped the middle $10 \%$ of observations based on the median value for the reverse Herfindahl-Hirschman Index. To ensure the results were not a function of this separation criteria, we changed the percentile selection criteria to achieve a greater separation between low (<40th percentile) and high ( $>60$ th percentile) competition subsamples. This approach (not shown) did not affect the results significantly.

\section{Model extensions ${ }^{7}$}

\subsection{Extension 1-Conditional process model}

To better inform theory and practice, we provide an extension (Fig. 5) of the basic conceptual framework shown in Fig. 2. This revised model is an adaptation of the Conditional Process Model (Hayes, 2013; Preacher et al., 2007) This extension proposes that Cumulative ISO 9001 Certifications and Competitive Intensity also have an indirect effect on firm performance through ISO 14001 Relative Timing. This is a likely scenario since a firm's timing of ISO 14001 implementation itself, may be influenced directly by competition and existing knowledge of standards. To model this scenario, we conduct analysis (Table 6, Column 1) using ISO 14001 Relative Timing as a dependent variable. The analysis shows that Competitive Intensity has no effect on ISO 14001Relative Timing. This is expected

\footnotetext{
${ }^{6}$ We thank the Associate Editor for suggesting this analysis.

7 We thank the Associate Editor and Reviewers for suggesting these extensions.
} 
Table 6

First-stage models for extensions 1 and 2.

\begin{tabular}{|c|c|c|}
\hline & DV = ISO 14001 & DV = ISO 14001 \\
\hline & $\begin{array}{l}\text { Relative timing } \\
\text { (extension } 1 \text { ) }\end{array}$ & $\begin{array}{l}\text { Implementation } \\
\text { (binary) (extension 2) }\end{array}$ \\
\hline$D V_{T}$ & $\begin{array}{l}-0.00 \\
(0.00)\end{array}$ & $\begin{array}{l}0.00 \\
(0.01)\end{array}$ \\
\hline Market Value & $\begin{array}{l}0.01 \\
(0.01)\end{array}$ & $\begin{array}{l}-0.16^{* *} \\
(0.08)\end{array}$ \\
\hline Capital Intensity & $\begin{array}{l}0.01 \\
(0.02)\end{array}$ & $\begin{array}{l}-0.01 \\
(0.31)\end{array}$ \\
\hline RED Intensity & $\begin{array}{l}-0.01 \\
(0.03)\end{array}$ & $\begin{array}{l}0.08 \\
(0.13)\end{array}$ \\
\hline Product Quality & $\begin{array}{l}0.13^{* * *} \\
(0.04)\end{array}$ & $\begin{array}{l}0.16 \\
(0.20)\end{array}$ \\
\hline Firm Size & $\begin{array}{l}0.06^{* * *} \\
(0.02)\end{array}$ & $\begin{array}{l}0.81^{* * *} \\
(0.12)\end{array}$ \\
\hline Munificence & $\begin{array}{l}0.00 \\
(0.00)\end{array}$ & $\begin{array}{l}-0.00 \\
(0.00)\end{array}$ \\
\hline Dynamism & $\begin{array}{l}0.00 \\
(0.00)\end{array}$ & $\begin{array}{l}0.01 \\
(0.01)\end{array}$ \\
\hline Competition & $\begin{array}{l}-0.06 \\
(0.06)\end{array}$ & $\begin{array}{l}-0.00 \\
(0.01)\end{array}$ \\
\hline Years Since First ISO 9001 & $0.18^{* * *}$ & $0.42^{* * *}$ \\
\hline Certification & $(0.03)$ & $(0.14)$ \\
\hline Cumulative ISO 9001 & $0.04^{*}$ & $0.22^{* *}$ \\
\hline Certifications & $(0.02)$ & $(0.11)$ \\
\hline Observations & 2329 & 2329 \\
\hline Wald's chi2 & 3149.12 & 209.06 \\
\hline
\end{tabular}

and can be explained as follows. Since (i) all firms in a given industry face similar levels of competitive intensity (as measured by HHI) and (ii) ISO 14001 Relative Timing is measured within each industry and not across industries, the expected average effect of

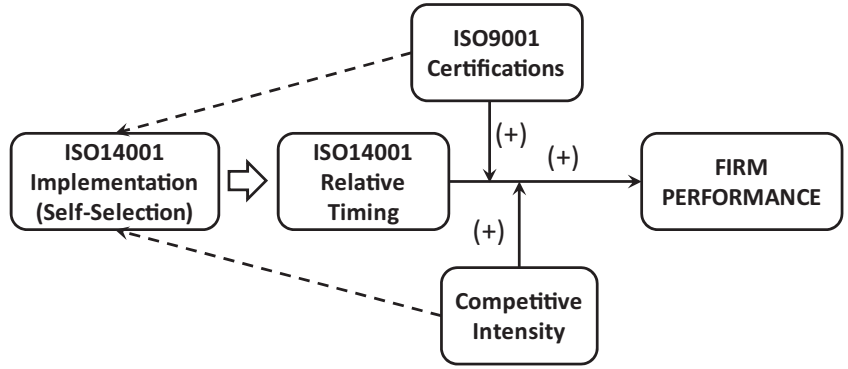

Fig. 6. Extension 2.

competitive intensity on ISO 14001 Relative Timing is 'zero'. Finally, there is a positive effect of Cumulative ISO 9001 Certifications on ISO 14001 Relative Timing, even after accounting for Years since first ISO 9001 certification (additional control). Overall, Cumulative ISO 9001 Certifications has a moderating as well as indirect effect (mediated through ISO 14001 Relative Timing) on firm performance.

\subsection{Extension 2-Heckman selection model}

In our main analysis, we had only retained firm-years of data after the first ISO 14001 certification had occurred for each firm. This was done to investigate the timing effect of ISO 14001 implementation, without confounding it with the event of implementing ISO 14001. Yet, this approach is prone to selection-bias since, as a result of our sampling procedure, we only "see" firms which have implemented i.e. selected themselves into ISO 14001 (Wooldridge, 2010). A more methodologically sophisticated approach would involve using a Heckman (1979) procedure (Fig. 6) which accounts for the drivers of ISO 14001 implementation decision (a binary variable) in the first stage. The Inverse Mills Ratio (which captures 'selection') obtained from this first-stage probit regression is then used as a control variable in the final models (Eqs. (1) and (2)).

Table 7

Second stage model for Heckman selection approach (extension 2).

\begin{tabular}{|c|c|c|c|c|c|c|c|c|c|c|c|c|}
\hline \multirow[t]{2}{*}{ Variables } & \multicolumn{6}{|c|}{ Main effects of ISO 14001 timing } & \multicolumn{6}{|c|}{ Moderating effects of cumulative ISO certifications } \\
\hline & Model 1 & Model 2 & Model 3 & Model 4 & Model 5 & Model 6 & Model 7 & Model 8 & Model 9 & Model 10 & Model 11 & Model 12 \\
\hline & $\mathrm{ROA}_{T+1}$ & $\mathrm{ROA}_{T+2}$ & $\operatorname{ROS}_{T+1}$ & $\operatorname{ROS}_{T+2}$ & $\mathrm{ROI}_{T+1}$ & $\mathrm{ROI}_{T+2}$ & $\mathrm{ROA}_{T+1}$ & $\mathrm{ROA}_{T+2}$ & $\operatorname{ROS}_{T+1}$ & $\operatorname{ROS}_{T+2}$ & $\mathrm{ROI}_{T+1}$ & $\mathrm{ROI}_{T+2}$ \\
\hline Inverse Mills Ratio & $\begin{array}{l}-0.46^{* *} \\
(0.21)\end{array}$ & $\begin{array}{l}-1.75^{* * * *} \\
(0.39)\end{array}$ & $\begin{array}{l}-1.42^{* * *} \\
(0.35)\end{array}$ & $\begin{array}{l}-3.21^{* * * *} \\
(0.63)\end{array}$ & $\begin{array}{l}-1.74^{*} \\
(0.99)\end{array}$ & $\begin{array}{l}-5.22^{* * *} \\
(2.29)\end{array}$ & $\begin{array}{l}-0.48^{* *} \\
(0.21)\end{array}$ & $\begin{array}{l}-1.63^{* * *} \\
(0.39)\end{array}$ & $\begin{array}{l}-1.45^{* * *} \\
(0.36)\end{array}$ & $\begin{array}{l}-3.31^{* * *} \\
(0.66)\end{array}$ & $\begin{array}{c}-1.79^{*} \\
(0.98)\end{array}$ & $\begin{array}{l}-7.70^{* * *} \\
(1.53)\end{array}$ \\
\hline Cumulative ISO 9001 & 0.14 & 0.06 & 0.10 & -0.01 & 0.40 & 0.26 & -0.00 & $-0.35^{* *}$ & -0.19 & $-0.75^{* *}$ & -0.06 & -1.07 \\
\hline Certifications & $(0.11)$ & $(0.16)$ & $(0.20)$ & $(0.34)$ & $(0.54)$ & $(1.05)$ & $(0.10)$ & $(0.16)$ & $(0.23)$ & $(0.36)$ & $(0.76)$ & $(1.09)$ \\
\hline ISO 14001 Relative Timing & $0.26^{* * *}$ & $0.48^{* * *}$ & 0.19 & $0.45^{* *}$ & 0.16 & 0.07 & 0.07 & 0.11 & -0.19 & -0.39 & -0.27 & $-2.28^{* *}$ \\
\hline $\begin{array}{l}\text { Cumulative ISO } 9001 \text { Certifications } \times \text { ISO } \\
14001 \text { Relative Timing }\end{array}$ & $(0.07)$ & $(0.11)$ & $(0.13)$ & $(0.21)$ & $(0.41)$ & $(0.93)$ & $\begin{array}{l}(0.10) \\
0.29^{* * *} \\
(0.10)\end{array}$ & $\begin{array}{l}(0.17) \\
0.63^{* * *} \\
(0.18)\end{array}$ & $\begin{array}{l}(0.22) \\
0.47^{* *} \\
(0.23)\end{array}$ & $\begin{array}{l}(0.32) \\
1.16^{* * *} \\
(0.35)\end{array}$ & $\begin{array}{l}(0.66) \\
0.60 \\
(0.72)\end{array}$ & $\begin{array}{l}(0.95) \\
2.43^{* *} \\
(1.00)\end{array}$ \\
\hline Observations & 543 & 441 & 543 & 441 & 543 & 443 & 543 & 441 & 543 & 441 & 543 & 441 \\
\hline Wald's chi2 & 6542.36 & 3121.23 & $16,338.85$ & 4998.58 & 2822.74 & 575.30 & 8975.83 & 3115.58 & $18,309.55$ & 1078.64 & 2783.32 & 2196.22 \\
\hline \multirow[t]{3}{*}{ Variables } & \multicolumn{6}{|c|}{ Effects under low competition } & \multicolumn{6}{|c|}{ Effects under high competition } \\
\hline & Model 13 & Model 14 & Model 15 & Model 16 & Model 17 & Model 18 & Model 19 & Model 20 & Model 21 & Model 22 & Model 23 & Model 24 \\
\hline & $\mathrm{ROA}_{T+1}$ & $\mathrm{ROA}_{T+2}$ & $\operatorname{ROS}_{T+1}$ & $\operatorname{ROS}_{T+2}$ & $\mathrm{ROI}_{T+1}$ & $\mathrm{ROI}_{T+2}$ & $\mathrm{ROA}_{T+1}$ & $\mathrm{ROA}_{T+2}$ & $\operatorname{ROS}_{T+1}$ & $\operatorname{ROS}_{T+2}$ & $\mathrm{ROI}_{T+1}$ & $\mathrm{ROI}_{T+2}$ \\
\hline Inverse Mills Ratio & $\begin{array}{c}-0.71^{*} \\
(0.40)\end{array}$ & $\begin{array}{l}-3.11^{* * *} \\
(0.67)\end{array}$ & $\begin{array}{l}-1.23 \\
(0.83)\end{array}$ & $\begin{array}{l}-3.24^{* *} \\
(1.35)\end{array}$ & $\begin{array}{l}-0.29 \\
(0.62)\end{array}$ & $\begin{array}{l}1.06 \\
(1.15)\end{array}$ & $\begin{array}{l}-0.55^{* *} \\
(0.24)\end{array}$ & $\begin{array}{l}-1.24^{* *} \\
(0.52)\end{array}$ & $\begin{array}{c}-0.44 \\
(0.58)\end{array}$ & $\begin{array}{l}-1.01 \\
(0.98)\end{array}$ & $\begin{array}{l}-0.34 \\
(2.31)\end{array}$ & $\begin{array}{l}1.95 \\
(4.20)\end{array}$ \\
\hline Cumulative ISO 9001 & 0.25 & -0.00 & 0.11 & -0.91 & $0.88^{*}$ & $2.08^{* * *}$ & $0.32^{* *}$ & $0.49^{*}$ & 0.37 & 0.74 & $2.45^{*}$ & $4.12^{* *}$ \\
\hline Certifications & $(0.21)$ & $(0.32)$ & $(0.45)$ & $(0.63)$ & $(0.47)$ & $(0.58)$ & $(0.16)$ & $(0.29)$ & $(0.31)$ & $(0.57)$ & $(1.30)$ & $(2.03)$ \\
\hline ISO 14001 Relative Timing & -0.06 & -0.04 & 0.19 & 0.49 & -0.28 & $-1.40^{* *}$ & $0.38^{* * *}$ & $0.85^{* * *}$ & 0.23 & $0.70^{* * *}$ & 1.10 & -1.00 \\
\hline & $(0.18)$ & $(0.24)$ & $(0.29)$ & $(0.39)$ & $(0.39)$ & $(0.61)$ & $(0.08)$ & $(0.18)$ & $(0.14)$ & $(0.23)$ & $(0.94)$ & $(1.50)$ \\
\hline Observations & 240 & 186 & 240 & 186 & 240 & 186 & 242 & 190 & 242 & 190 & 242 & 190 \\
\hline Wald's chi2 & 1811.76 & 791.75 & 1351.74 & $24,572.74$ & 1615.25 & 626.95 & 5270.99 & 2121.28 & 9816.43 & 971.36 & $15,717.53$ & 141.24 \\
\hline
\end{tabular}

* $p<0.1$; only relevant variables shown; all controls were included; all Wald's statistics were significant at $p<0.001$; heteroskedastic panel structure used; AR1 serial

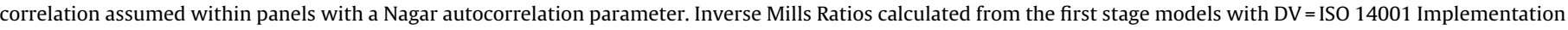
(Binary).

*** $p<0.05$.

** $p<0.01$. 
Table 8

Strategic framework of the timing decision.

\begin{tabular}{lll}
\hline & $\begin{array}{l}\text { Low competitive } \\
\text { intensity }\end{array}$ & $\begin{array}{l}\text { High competitive } \\
\text { intensity }\end{array}$ \\
\hline Low absorptive capacity & $\begin{array}{l}\text { Quadrant I: late } \\
\text { mover advantage } \\
\text { High absorptive capacity } \\
\text { mover advantage }\end{array}$ & $\begin{array}{l}\text { Quadrant III: trade-off } \\
\text { Quadrant IV: early } \\
\text { mover advantage }\end{array}$ \\
\hline
\end{tabular}

A significant effect for the Inverse Mills Ratio (Table 7) indicates the presence of selection bias (at least to some degree). Extension 2 provides a more realistic view of the actual setting faced by managers, by going beyond the basic conceptual framework. Table 7 shows that all our hypotheses are also strongly supported by this approach, which reduces concerns about selection bias.

\section{Discussion and conclusion}

This study offers several contributions to both theory and practice of implementing ISO management standards. Over the years ISO management standards "give world-class specifications for products, services and systems, to ensure quality, safety and efficiency", which promote and facilitate global trade ${ }^{8}$. Research has investigated financial and operational benefits of implementing various ISO management standards. However, research has not investigated the strategic importance of the deciding when to implement ISO management standards. The timing decision becomes even more important given that ISO standards seek to achieve a certain degree of isomorphism between firms (e.g. ISO 9001 assures customers that their supplier has implemented standard components of a quality system), which reduces heterogeneity in firm resources that could potentially generate a competitive advantage. However, our study argues that the implementation timing decision can potentially lead to a performance advantage, which prior studies did not fully address. From a strategy-performance relationship standpoint, we show performance benefits of an early implementation strategy, but these benefits depends on the level of competitive intensity and the firm's absorptive capacity.

The analysis shows that firms benefit from early implementation of ISO 14001 in more competitive environments, but do not benefit in less competitive environments. In high competitive environments, an average size firm in our sample (with revenues approximately $\$ 8$ billion) that implements ISO 14001 1-year earlier than the average of their industry competitors improves their ROA by $7-10 \%$ and ROS by $6-9 \%$ on average, holding all other factors constant. However, early implementation in a low competitive environment does not significanly change ROA, ROS or ROI. The moderating effect of absorptive capacity (see Table 5 and Fig. 4) provide further interesting implications for the timing decision. When firms have significant prior related experience in ISO 9001, implementing ISO 14001 earlier than the competition provides additional performance benefits (especially for ROA and ROS) over firms without much prior experience. In fact, firms with limited experience would actually be better off if they implement the ISO 14001 standard later than their average peers (see Fig. 4).

Table 8 offers a strategic framework for the timing decision based on the empirical results. Each quadrant in Table 8 gives the best strategic action based on the levels of absorptive capacity and competitive intensity. For firms situated in low competitive

8 http://www.iso.org/iso/home/about.htm. intensity environment (quadrant I and II), the adoption timing decision depends on how much absorptive capacity they have. In a low competition environment, firms can benefit more from the early implementation strategy only if they have high absorptive capacity (quadrant II). However, firms in a less competitive environment and with limited knowledge of a related standard benefit from implementing later than the industry average (quadrant I). In other words, quadrant II firms rely on internally accumulated knowledge (i.e. absorptive capacity) while quadrant I firms rely on externally accumulated knowledge, which takes time to accumulate (i.e. industry best practices). For firms in quadrant IV, implementing earlier than the industry average provides the most benefits. Consequently these firms can get an early mover advantage. For firms situated in quadrant III (low absorptive capacity and high competitive intensity), they face a more difficult decision. High competitive intensity environment favors an early implementation strategy while low absorptive capacity favors a later implementation strategy, which makes the decision more difficult. How to effectively navigate in a highly competitive industry with little prior related knowledge remains an interesting future research question.

Our study has interesting theoretical implications as well. Most studies in operations strategy draw on the Resource Based View (RBV) (Barney, 1991) to argue that heterogeneity in difficult to imitate resources account for how a firm can get competitive advantage and high performance. However, the ISO standards encourage certain degree of isomorphism across organizations, which reduce heterogeneity in performance between competitors. Since ISO management standards promote imitation, the competitive advantage becomes questionable. But, we conceptually argue and empirically show that the timing of standard adoption is a source of competitive advantage and high performance. However, one needs to be cautious in generalizing the results of this study. For instance, an early mover advantage may be less important of an issue when the practices require a very high level of customization to fit the business context (Jacobs et al., 2015). For example, some consider the Toyota Production System a complex amalgamation of practices that uniquely fit their context, that is, it's an inimitable resource (Rivkin, 2000). In this setting, implementation timing may be less critical. We encourage future research to consider both perspectives to examine the relationships between operational practices (e.g. Six Sigma) and competitive advantage.

The results in this study offer practical insights for firms deciding when to implement new emerging management standards as well. The International Standards Organization has designed ISO 28001 (supply chain resilience) to be compatible with ISO 9001, similar to ISO 14001 (Branch, 2008). Although the current installation base for ISO 28001 is still too small to conduct meaningful analyses, future research could examine if this study's results still hold true for firms implementing all three compatible standards sequentially (ISO 9001, ISO 14001, and ISO 28001). This study gives useful insights about how managers might frame and think about the timing decision. Future studies can explore other factors that might affect the timing-performance benefit relationship. In addition, future research could extend this study to other implementation contexts for compatible standards in healthcare (HIMMS) and automotive (SAE) industries, to name a few. We hope this study triggers more research on topics related to implementation timing strategy and firm performance.

\section{Appendix A.}

Tables A1 and A2. 
Table A1

Accounting for serial correlation and endogeneity in lagged dependent variables.

\begin{tabular}{|c|c|c|c|c|c|c|c|c|c|c|c|c|}
\hline \multirow[t]{2}{*}{ Variables } & \multicolumn{6}{|c|}{ Main effects of ISO 14001 timing } & \multicolumn{6}{|c|}{ Moderating effects of cumulative ISO 9001 certifications } \\
\hline & $\mathrm{ROA}_{T+1}$ & $\mathrm{ROA}_{T+2}$ & $\operatorname{ROS}_{T+1}$ & $\operatorname{ROS}_{T+2}$ & $\mathrm{ROI}_{T+1}$ & $\mathrm{ROI}_{T+2}$ & $\mathrm{ROA}_{T+1}$ & $\mathrm{ROA}_{T+2}$ & $\operatorname{ROS}_{T+1}$ & $\operatorname{ROS}_{T+2}$ & $\mathrm{ROI}_{T+1}$ & $\mathrm{ROI}_{T+2}$ \\
\hline $\mathrm{DV}_{T_{-} \text {INSTRUMENTED }}$ & $\begin{array}{l}0.92^{* * *} \\
(0.04)\end{array}$ & $\begin{array}{l}0.70^{* * *} \\
(0.05)\end{array}$ & $\begin{array}{l}0.65^{* * *} \\
(0.07)\end{array}$ & $\begin{array}{l}0.50^{* * *} \\
(0.05)\end{array}$ & $\begin{array}{l}0.68^{* * *} \\
(0.11)\end{array}$ & $\begin{array}{l}0.44^{* * *} \\
(0.14)\end{array}$ & $\begin{array}{l}0.91^{* * *} \\
(0.04)\end{array}$ & $\begin{array}{l}0.67^{* * *} \\
(0.05)\end{array}$ & $\begin{array}{l}0.50^{* * *} \\
(0.05)\end{array}$ & $\begin{array}{l}0.65^{* * *} \\
(0.07)\end{array}$ & $\begin{array}{l}0.66^{* * *} \\
(0.11)\end{array}$ & $\begin{array}{l}0.54^{* * *} \\
(0.12)\end{array}$ \\
\hline Cumulative ISO 9001 Certifications & $\begin{array}{l}0.78^{* * *} \\
(0.15)\end{array}$ & $\begin{array}{l}1.00^{* * *} \\
(0.16)\end{array}$ & $\begin{array}{l}1.01^{* * *} \\
(0.28)\end{array}$ & $\begin{array}{l}0.77^{* * * *} \\
(0.29)\end{array}$ & $\begin{array}{l}1.42^{* * *} \\
(0.51)\end{array}$ & $\begin{array}{l}1.84^{* *} \\
(0.85)\end{array}$ & $\begin{array}{l}0.45^{* * *} \\
(0.16)\end{array}$ & $\begin{array}{l}0.31^{* *} \\
(0.15)\end{array}$ & $\begin{array}{l}0.36 \\
(0.33)\end{array}$ & $\begin{array}{l}0.49^{*} \\
(0.27)\end{array}$ & $\begin{array}{l}1.13^{*} \\
(0.62)\end{array}$ & $\begin{array}{l}1.09 \\
(0.79)\end{array}$ \\
\hline ISO 14001 Relative Timing & $\begin{array}{l}0.08 \\
(0.12)\end{array}$ & $\begin{array}{l}0.26^{*} \\
(0.14)\end{array}$ & $\begin{array}{l}0.25 \\
(0.18)\end{array}$ & $\begin{array}{l}0.49^{* *} \\
(0.22)\end{array}$ & $\begin{array}{l}-0.47 \\
(0.50)\end{array}$ & $\begin{array}{l}-0.03 \\
(0.88)\end{array}$ & $\begin{array}{l}-0.25 \\
(0.18)\end{array}$ & $\begin{array}{l}-0.44^{* *} \\
(0.20)\end{array}$ & $\begin{array}{l}0.13 \\
(0.36)\end{array}$ & $\begin{array}{l}-0.62^{*} \\
(0.34)\end{array}$ & $\begin{array}{l}-1.00 \\
(0.68)\end{array}$ & $\begin{array}{l}-1.97^{* *} \\
(0.91)\end{array}$ \\
\hline $\begin{array}{l}\text { Cumulative ISO } 9001 \text { Certifications } \times \text { ISO } \\
14001 \text { Relative Timing }\end{array}$ & & & & & & & $\begin{array}{l}0.50^{* * *} \\
(0.19)\end{array}$ & $\begin{array}{l}0.98^{* * *} \\
(0.21)\end{array}$ & $\begin{array}{l}0.44 \\
(0.37)\end{array}$ & $\begin{array}{l}0.95^{* * *} \\
(0.32)\end{array}$ & $\begin{array}{l}0.97 \\
(0.74)\end{array}$ & $\begin{array}{l}2.02^{* *} \\
(1.00)\end{array}$ \\
\hline Observations & 526 & 424 & 526 & 424 & 526 & 426 & 526 & 424 & 424 & 526 & 526 & 424 \\
\hline Wald's chi2 & 3008.38 & 6210.87 & 1359.15 & 1328.71 & 518.89 & 510.23 & 2887.00 & 2834.01 & 1001.85 & 1145.41 & 504.00 & 1615.92 \\
\hline \multirow[t]{2}{*}{ Variables } & \multicolumn{6}{|c|}{ Effects under low competition } & \multicolumn{6}{|c|}{ Effects under high competition } \\
\hline & $\mathrm{ROA}_{T+1}$ & $\mathrm{ROA}_{T+2}$ & $\operatorname{ROS}_{T+1}$ & $\operatorname{ROS}_{T+2}$ & $\mathrm{ROI}_{T+1}$ & $\mathrm{ROI}_{T+2}$ & $\mathrm{ROA}_{T+1}$ & $\mathrm{ROA}_{T+2}$ & $\operatorname{ROS}_{T+1}$ & $\operatorname{ROS}_{T+2}$ & $\mathrm{ROI}_{T+1}$ & $\mathrm{ROI}_{T+2}$ \\
\hline $\mathrm{DV}_{T_{-I N S T R U M E N T E D}}$ & $\begin{array}{l}0.86^{* * *} \\
(0.07)\end{array}$ & $\begin{array}{l}0.48^{* * *} \\
(0.08)\end{array}$ & $\begin{array}{l}0.55^{* * *} \\
(0.06)\end{array}$ & $\begin{array}{l}1.41^{* * *} \\
(0.12)\end{array}$ & $\begin{array}{l}0.42^{* * *} \\
(0.12)\end{array}$ & $\begin{array}{l}0.29^{* *} \\
(0.12)\end{array}$ & $\begin{array}{l}1.09^{* * *} \\
(0.04)\end{array}$ & $\begin{array}{l}0.91^{* * *} \\
(0.07)\end{array}$ & $\begin{array}{l}0.38^{* * *} \\
(0.10)\end{array}$ & $\begin{array}{l}1.10^{* * *} \\
(0.15)\end{array}$ & $\begin{array}{l}1.28^{* * *} \\
(0.32)\end{array}$ & $\begin{array}{l}0.70 \\
(0.45)\end{array}$ \\
\hline Cumulative ISO 9001 & $1.26^{* * *}$ & $1.47^{* * *}$ & $0.81^{*}$ & $1.15^{* * *}$ & $1.61^{* * *}$ & $1.11^{* *}$ & $0.95^{* * *}$ & $0.95^{* * *}$ & 0.19 & $1.51^{* * *}$ & $4.01^{* * *}$ & 2.90 \\
\hline Certifications & $(0.31)$ & $(0.36)$ & $(0.42)$ & $(0.39)$ & $(0.57)$ & $(0.51)$ & $(0.20)$ & $(0.30)$ & $(0.29)$ & $(0.55)$ & $(1.40)$ & $(2.30)$ \\
\hline ISO 14001 Relative Timing & $\begin{array}{l}-0.35 \\
(0.25)\end{array}$ & $\begin{array}{l}-0.33 \\
(0.30)\end{array}$ & $\begin{array}{l}0.77^{* *} \\
(0.34)\end{array}$ & $\begin{array}{l}0.10 \\
(0.20)\end{array}$ & $\begin{array}{l}-0.64 \\
(0.47)\end{array}$ & $\begin{array}{l}-1.17^{*} \\
(0.61)\end{array}$ & $\begin{array}{l}0.28^{* *} \\
(0.11)\end{array}$ & $\begin{array}{l}0.57^{* * *} \\
(0.19)\end{array}$ & $\begin{array}{l}0.07 \\
(0.46)\end{array}$ & $\begin{array}{l}0.59^{* *} \\
(0.25)\end{array}$ & $\begin{array}{l}0.27 \\
(1.19)\end{array}$ & $\begin{array}{l}-0.85 \\
(1.71)\end{array}$ \\
\hline Observations & 233 & 179 & 233 & 232 & 233 & 179 & 232 & 180 & 179 & 180 & 232 & 180 \\
\hline Wald's chi2 & 959.68 & 572.73 & 3359.15 & 1401.40 & 426.61 & 336.16 & 9096.06 & 1976.20 & 4654.91 & 1356.07 & 587.45 & 320.32 \\
\hline
\end{tabular}

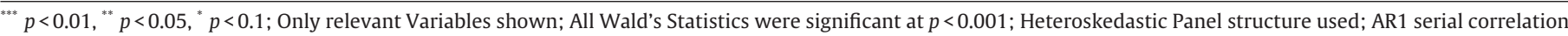

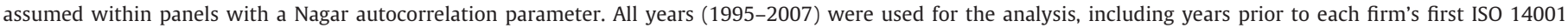
implementation. $\mathrm{DV}_{T_{\perp} \text { INSTRUMENTED }}$ was created using past values of dependent variable.

Table A2

Accounting for cumulative ISO 9001 certifications (ex-ante).

\begin{tabular}{|c|c|c|c|c|c|c|c|c|c|c|c|c|}
\hline \multirow[t]{2}{*}{ Variables } & \multicolumn{6}{|c|}{ Main effects of ISO 14001 timing } & \multicolumn{6}{|c|}{ Moderating effects of cumulative ISO certifications } \\
\hline & Model 1 & Model 2 & Model 3 & Model 4 & Model 5 & Model 6 & Model 7 & Model 8 & Model 9 & Model 10 & Model 11 & Model 12 \\
\hline & $\mathrm{ROA}_{T+1}$ & $\mathrm{ROA}_{T+2}$ & $\operatorname{ROS}_{T+1}$ & $\operatorname{ROS}_{T+2}$ & $\mathrm{ROI}_{T+1}$ & $\mathrm{ROI}_{T+2}$ & $\mathrm{ROA}_{T+1}$ & $\mathrm{ROA}_{T+2}$ & $\operatorname{ROS}_{T+1}$ & $\operatorname{ROS}_{T+2}$ & $\mathrm{ROI}_{T+1}$ & $\mathrm{ROI}_{T+2}$ \\
\hline Cumulative ISO 9001 & $0.45^{* * *}$ & $1.31^{* * *}$ & $0.50^{*}$ & $1.12^{* * *}$ & 0.79 & 2.30 & $0.29^{*}$ & $0.45^{* *}$ & 0.34 & 0.01 & 0.08 & 0.30 \\
\hline Certifications (Ex-ante) & $(0.15)$ & $(0.22)$ & $(0.28)$ & $(0.42)$ & $(0.83)$ & $(1.66)$ & $(0.15)$ & $(0.23)$ & $(0.30)$ & $(0.39)$ & $(1.04)$ & $(1.11)$ \\
\hline ISO 14001 Relative & $0.31^{* * * *}$ & $0.50^{* * *}$ & 0.20 & $0.51^{* * *}$ & 0.36 & 0.24 & 0.19 & -0.15 & 0.07 & -0.51 & -0.48 & $-3.29^{* * *}$ \\
\hline \multirow[t]{3}{*}{ Timing } & $(0.07)$ & $(0.11)$ & $(0.14)$ & $(0.19)$ & $(0.38)$ & $(0.86)$ & $(0.14)$ & $(0.24)$ & $(0.28)$ & $(0.40)$ & $(0.83)$ & $(1.16)$ \\
\hline & & & & & & & 0.25 & $0.99^{* * *}$ & 0.18 & $1.32^{* * *}$ & 1.05 & $3.96^{* * *}$ \\
\hline & & & & & & & $(0.19)$ & $(0.32)$ & $(0.33)$ & $(0.47)$ & $(1.10)$ & $(1.38)$ \\
\hline Observations & 543 & 441 & 543 & 441 & 543 & 443 & 543 & 441 & 543 & 441 & 543 & 441 \\
\hline Wald's chi2 & 6909.21 & 3896.88 & $19,959.44$ & 1053.01 & 2355.86 & 118.51 & 7749.33 & 2584.56 & $24,816.54$ & 1000.05 & 2499.78 & 2012.45 \\
\hline \multirow[t]{3}{*}{ Variables } & \multicolumn{6}{|c|}{ Effects under low competition } & \multicolumn{6}{|c|}{ Effects under high competition } \\
\hline & Model 13 & Model 14 & Model 15 & Model 16 & Model 17 & Model 18 & Model 19 & Model 20 & Model 21 & Model 22 & Model 23 & Model 24 \\
\hline & $\mathrm{ROA}_{T+1}$ & $\mathrm{ROA}_{T+2}$ & $\operatorname{ROS}_{T+1}$ & $\operatorname{ROS}_{T+2}$ & $\mathrm{ROI}_{T+1}$ & $\mathrm{ROI}_{T+2}$ & $\mathrm{ROA}_{T+1}$ & $\mathrm{ROA}_{T+2}$ & $\operatorname{ROS}_{T+1}$ & $\operatorname{ROS}_{T+2}$ & $\mathrm{ROI}_{T+1}$ & $\mathrm{ROI}_{T+2}$ \\
\hline Cumulative ISO 9001 & $0.84^{* * *}$ & $1.92^{* * *}$ & 0.22 & 0.66 & $1.05^{* *}$ & $3.61^{* * *}$ & $0.51^{* *}$ & $1.70^{* * *}$ & 0.61 & $2.77^{* * *}$ & $5.45^{* * *}$ & $6.03^{*}$ \\
\hline Certifications (Ex-ante) & $(0.32)$ & $(0.46)$ & $(0.44)$ & $(0.48)$ & $(0.52)$ & $(0.81)$ & $(0.21)$ & $(0.37)$ & $(0.44)$ & $(0.72)$ & $(1.72)$ & $(3.22)$ \\
\hline ISO 14001 Relative Timing & 0.01 & -0.06 & 0.23 & 0.19 & -0.18 & $-0.92^{*}$ & $0.43^{* * *}$ & $0.84^{* * *}$ & $0.33^{* *}$ & $0.86^{* * *}$ & 0.74 & 0.54 \\
\hline & $(0.17)$ & $(0.25)$ & $(0.29)$ & $(0.41)$ & $(0.37)$ & $(0.54)$ & $(0.08)$ & $(0.17)$ & $(0.14)$ & $(0.21)$ & $(0.98)$ & $(1.51)$ \\
\hline Observations & 240 & 186 & 240 & 186 & 240 & 186 & 242 & 190 & 242 & 190 & 242 & 190 \\
\hline Wald's chi2 & 1894.46 & 957.06 & 1387.21 & 4575.85 & 1328.63 & 1160.79 & 4880.11 & 5433.03 & 7709.54 & 1726.38 & $115,152.33$ & 131.48 \\
\hline
\end{tabular}

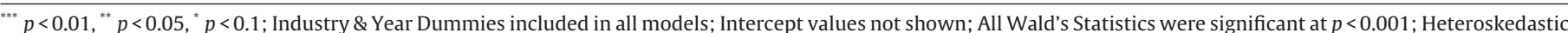

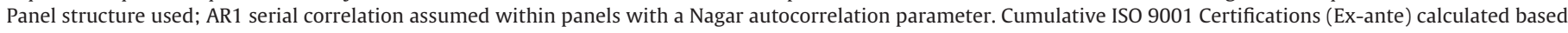
on certifications at the time of first ISO14001 implementation.

\section{References}

Albuquerque, P., Bronnenberg, B.J., Corbett, C.J., 2007. A spatiotemporal analysis of the global diffusion of ISO 9000 and ISO 14000 certification. Manage. Sci. 53, 451-468.

Arnold, H.J., 1982. Moderator variables: a clarification of conceptual, analytic, and psychometric issues. Organ. Behav. Hum. Perform. 29, 143-174.

Bain, J.S., 1951. Relation of profit rate to industry concentration: American manufacturing, 1936-1940. Q. J. Econ. 65, 293-324.

Bansal, P., Hunter, T., 2003. Strategic explanations for the early adoption of ISO 14001. J. Bus. Ethics 46, 289-299.

Barber, B.M., Lyon, J.D., 1996. Detecting abnormal operating performance: the empirical power and specification of test statistics. J. Finan. Econ. 41, 359399.
Barnett, W.P., McKendrick, D.G., 2004. Why are some organizations more competitive than others? Evidence from a changing global market. Admin. Sci. Q. 49, $535-571$.

Barney, J., 1991. Firm resources and sustained competitive advantage. J. Manage. 17, 99.

Baum, J., Wally, S., 2003. Strategic decision speed and firm performance. Strategic Manage. J. 24, 1107-1129.

Benner, M.J., Tushman, M., 2002. Process Management and Technological Innovation: a Longitudinal Study of the Photography and Paint Industries. Admin. Sci. O. 47, 676 .

Benner, M.J., Veloso, F.M., 2008. ISO 9000 practices and financial performance: a technology coherence perspective. J. Oper. Manage. 26, 611-629.

Boiral, O., 2011. Managing with ISO systems: lessons from practice. Long Range Plann. 44, 197-220. 
Branch, A.E., 2008. Global Supply Chain Management and International Logistics. Taylor \& Francis, New York, NY.

Carow, K., Heron, R., Saxton, T., 2004. Do early birds get the returns? An empirical investigation of early-mover advantages in acquisitions. Strategic Manage. J. 25, 563-585.

Carpenter, G.S., Nakamoto, K., 1989. Consumer preference formation and pioneering advantage. J. Marketing Res. 26, 285-298.

Chen, M.-J., 1996. Competitor analysis and interfirm rivalry: toward a theoretical integration. Acad. Manage. Rev. 21, 100-134.

Chung, K.H., Pruitt, S.W., 1994. A simple approximation of Tobin's q. Finan. Manage. 23, 23.

Cohen, W.M., Levinthal, D.A., 1989. Innovation and learning: the two faces of R \& D. Econ. J. 99 (397), 569-596.

Cohen, W.M., Levinthal, D.A., 1990. Absorptive capacity: a new perspective on learning and innovation. Admin. Sci. Q. 35, 128-152.

Corbett, C.J., Kirsch, D.A., 2001. International diffusion of ISO 14000 certification. Prod. Oper. Manage. 10, 327-342.

Corbett, C.J., Montes-Sancho, M.J., Kirsch, D.A., 2005. The financial impact of ISO 9000 certification in the United States: an empirical analysis. Manage. Sci. 51, 1046-1059.

Corbett, C.J., 2006. Global diffusion of ISO 9000 certification through supply chains. Manuf. Serv. Oper. Manage. 8, 330-350.

Damodaran, A., 2012. Investment Valuation: Tools and Techniques for Determining the Value of Any Asset. John Wiley \& Sons, New Jersey.

D'Aveni, R.A., Dagnino, G.B., Smith, K.G., 2010. The age of temporary advantage. Strategic Manage. J. 31, 1371-1385.

D’Aveni, R.A., 1994. Hypercompetition. The Free Press, New York, NY.

de Jong, P., Paulraj, A., Blome, C., 2014. The financial impact of ISO 14001 certification: top-line, bottom-line, or both? J. Bus. Ethics 119, 131-149.

Derfus, P.J., Maggitti, P.G., Grimm, C.M., Smith, K.G., 2008. The red queen effect: competitive actions and firm performance. Acad. Manage. J. 51, 61-80.

Dess, G.G., Beard, D.W., 1984. Dimensions of organizational task environments. Admin. Sci. Q. 29, 52-73.

Docking, D.S., Dowen, R.J., 1999. Market interpretation of ISO 9000 registration. J. Finan. Res. 22, 147-160.

Ferrier, W.J., Smith, K.G., Grimm, C.M., 1999. The role of competitive action in market share erosion and industry dethronement: a study of industry leaders and challengers. Acad. Manage. J. 42, 372-388.

Gedajlovic, E., Shapiro, D.M., 2002. Ownership structure and firm profitability in Japan. Acad. Manage. J. 45, 565-575.

Gray, J.V., Anand, G., Roth, A.V., 2015. The influence of ISO 9000 certification on process compliance. Prod. Oper. Manage. 24 (March 3), 369-382.

Greene, W.H., 2003. Econometric Analysis, fifth ed. Prentice Hall, New Jersey.

Grimm, C., Lee, H., Smith, K., 2005. Strategy as Action: Competitive Dynamics and Competitive Advantage. Oxford University Press, Oxford, UK.

Hair, J.F., Black, W.C., Babin, B.J., Anderson, R.E., Tatjam, R.L., 2006. Mutivariate Data Analysis, seventh ed. Pearson Education International, Upper Saddle River, New Jersey.

Hayes, A.F., 2013. Introduction to Mediation, Moderation, and Conditional Process Analysis: A Regression-based Approach. Guilford Press, New York, NY.

Heckman, J.J., 1979. Sample selection bias as a specification error. Econometrica 47 (1), 153-161.

Heras-Saizarbitoria, I., Molina-Azorín, J.F., Dick, G.P., 2011. ISO 14001 certification and financial performance: selection-effect versus treatment-effect. J. Cleaner Prod. 19, 1-12

Hufbauer, G., Kotschwar, B., Wilson, J., 2002. Trade and standards: a look at Central America. World Economy 25, 991-1018.

ISO, 2008. The Integrated Use Of Management System Standards. International Organization for Standardization, Switzerland.

ISO, 2012. The ISO Survey of Certifications 2012. ISO, Geneva, Switzerland.

Jacobs, B., Swink, M., Linderman, K., 2015. Performance effects of early and late six sigma adoptions. J. Oper. Manage., http://dx.doi.org/10.1016/j.jom.2015.01.002

Jacobson, R., 1987. The validity of ROI as a measure of business performance. Am. Econ. Rev. 77, 470-478.

Kantor, P.B., Zangwill, W.I., 1991. Theoretical foundation for a learning rate budget. Manage. Sci. 37, 315-330.

King, A., Lenox, M., 2002. Exploring the locus of profitable pollution reduction. Manage. Sci. 48, 289-299.

King, A.A., Lenox, M.J., Terlaak, A., 2005. The strategic use of decentralized institutions: exploring certification with the ISO 14001 management standard. Acad. Manage. J. 48, 1091-1106.

Lapré, M.A., Nembhard, I.M., 2011. Inside the Organizational Learning Curve: Understanding the Organizational Learning Process, vol. 4. Foundations and Trends $₫$ in Technology, Information and Operations Management, pp. 1-103.

Levine, D.I., Toffel, M.W., 2010. Quality management and job quality: how the ISO 9001 standard for quality management systems affects employees and employers. Manage. Sci. 56, 978-996.

Lieberman, M.B., Montgomery, D.B., 1988. First-mover advantages. Strategic Manage. J. 9, 41-58.

Link, S., Naveh, E., 2006. Standardization and discretion: does the environmental standard ISO 14001 lead to performance benefits? IEEE Trans. Eng. Manage. 53, 508-519.
Lissenden, J., 1999. ISO 9000 Eases ISO 14001 Registration, available at http://www qualitydigest.com/may99/html/iso9000.html (accessed 22.01.14).

3M, 2012. 3M Sustainability Report, Retrieved 2014, from 〈http://solutions.3m. com/wps/portal/3M/en_US/3M-Sustainability/Global/Resources/Downloads/).

Maddala, G.S., 1983. Limited-dependent and Qualitative Variables in Econometrics. Cambridge University Press, Cambridge, United Kingdom.

Martínez-Costa, M., Choi, T.Y., Martínez, J.A., Martínez-Lorente, A.R., 2009. ISO 9000/1994, ISO 9001/2000 and TQM: the performance debate revisited. J. Oper. Manage. 27, 495-511.

Michael Geringer, J., Beamish, P.W., DaCosta, R.C., 1989. Diversification strategy and internationalization: implications for MNE performance. Strategic Manage. J. 10 109-119.

Miller, D., Chen, M.-J., 1994. Sources and consequences of competitive inertia: a study of the US airline industry. Admin. Sci. Q. 39 (1), 1-23.

Montabon, F., Melnyk, S.A., Sroufe, R., Calantone, R.J., 2000. ISO 14000 assessing its perceived impact on corporate performance. J. Supply Chain Manage. 36, 4-16.

Morrow, D., Rondinelli, D., 2002. Adopting corporate environmental management systems: motivations and results of ISO 14001 and EMAS certification. Eur. Manage. J. 20, 159-171.

Mowery, D.C., Oxley, J.E., 1995. Inward technology transfer and competitiveness: the role of national innovation systems. Camb. J. Econ. 19, 67-93.

Nair, A., Prajogo, D., 2009. Internalisation of ISO 9000 standards: the antecedent role of functionalist and institutionalist drivers and performance implications. Int. J. Prod. Res. 47, 4545-4568.

Naveh, E., Marcus, A., 2005. Achieving competitive advantage through implementing a replicable management standard: installing and using ISO 9000. J. Oper. Manage. 24, 1-26.

Preacher, K.J., Rucker, D.D., Hayes, A.F., 2007. Addressing moderated mediation hypotheses: theory, methods, and prescriptions. Multivariate Behav. Res. 42, $185-227$.

Prescott, J.E., 1986. Environments as moderators of the relationship between strategy and performance. Acad. Manage. J. 29, 329-346.

Rivkin, J.W., 2000. Imitation of complex strategies. Manage. Sci. 46, 824-844

Scherer, F.M., Ross, D., 1990. Industrial Market Structure and Economic Performance. University of Illinois at Urbana-Champaign's Academy for Entrepreneurial Leadership Historical Research Reference in Entrepreneurship, Champaign, IL.

Schumpeter, J.A., 2008. Capitalism, Socialism and Democracy. Harper Perennia Modern Classics, New York, NY.

Simmons, B.L., White, M.A., 1999. The relationship between ISO 9000 and business performance: does registration really matter? J. Managerial Issues 11 (3) 330-343.

Singh, P.J., Power, D., Chuong, S.C., 2011. A resource dependence theory perspective of ISO 9000 in managing organizational environment. J. Oper. Manage. 29, 49-64.

Smith, T., 2006. Management System Standards: Challenges and Opportunities for the Future, Retrieved 2014, from 〈http://www.inlac.org.co/web/images/ stories/actualidad/sistemasdegestioncambiosyvision.pdf $\rangle$.

Terziovski, M., Samson, D., Dow, D., 1997. The business value of quality management systems certification. Evidence from Australia and New Zealand. J. Oper. Manage. $15,1-18$.

Terziovski, M., Power, D., Sohal, A.S., 2003. The longitudinal effects of the ISO 9000 certification process on business performance. Eur. J. Oper. Res. 146, 580-595.

VanderWerf, P.A., Mahon, J.F., 1997. Meta-analysis of the impact of research methods on findings of first-mover advantage. Manage. Sci. 43, 1510-1519.

Vasudeva, G., Anand, J., 2011. Unpacking absorptive capacity: a study of knowledge utilization from alliance portfolios. Acad. Manage. J. 54, 611-623.

Venkatraman, N., 1989. The concept of fit in strategy research: toward verbal and statistical correspondence. Acad. Manage. Rev. 14, 423-444.

Veugelers, R., 1997. Internal R \& D expenditures and external technology sourcing. Res. Policy 26, 303-315

Waddock, S.A., Graves, S.B., 1997. The corporate social performance. Strategic Manage. J. 8, 303-319.

Wiggins, R.R., Ruefli, T.W., 2002. Sustained competitive advantage: temporal dynamics and the incidence and persistence of superior economic performance. Organ. Sci. 13, 81-105

Wilson, R.C., 2001. Ford spreads the word about its EMS success. Pollut. Eng. 33 32-33.

Wooldridge, J.M., 2010. Econometric Analysis of Cross Section and Panel Data. The MIT Press, Cambridge, MA.

Yeung, A.C., Lo, C.K., Cheng, T., 2011. Behind the iron cage: an institutional perspective on ISO 9000 adoption and CEO compensation. Organ. Sci. 22, 1600-1612.

Young, G., Smith, K.G., Grimm, C.M., 1996. "Austrian” and industrial organization perspectives on firm-level competitive activity and performance. Organ. Sci. 7, 243-254.

Zahra, S.A., George, G., 2002. Absorptive capacity: a review, reconceptualization, and extension. Acad. Manage. Rev., 185-203.

Zhang, Y., Rajagopalan, N., 2010. Once an outsider, always an outsider? CEO origin, strategic change, and firm performance. Strategic Manage. J. 31, 334-346. 